\title{
Relationship between Human Resources Management Practices, Transformational Leadership, and Knowledge Sharing on Innovation in Iranian Electronic Industry
}

\author{
Mahmoud Manafi ${ }^{1} \&$ Indra Devi Subramaniam ${ }^{1}$ \\ ${ }^{1}$ GSM, Multimedia University, Malaysia \\ Correspondence: Mahmoud Manafi, GSM, Multimedia University, Malaysia. E-mail: \\ mahmoud_manafi@yahoo.com; indra@mmu.edu.my
}

Received: November 14, 2014 Accepted: February 3, 2015 Online Published: April 21, 2015

doi:10.5539/ass.v11n10p358 URL: http://dx.doi.org/10.5539/ass.v11n10p358

\begin{abstract}
Electronic industry needs innovation to survive, and also to compete internationally. This study examines factors that can enhance technical innovation of companies in the electronic industry of Iran. The main purpose of this study is to examine the relationship between human resource management practices, transformational leadership, knowledge sharing, and innovation of the large and major electronic companies.

More specifically, the research attempts to examine whether knowledge sharing mediates the relationship between human resource management practices and transformational leadership with innovation. A quantitative research approach was used in this study. A cross-sectional correlational research design was used.

The sample for this study was drawn from a population of 23,704 employees (managers, engineers, and expert technicians) of eight largest electronic companies in Iran using stratified sampling method. The sample size was 376.

After exploratory Factor Analysis (EFA) and confirmatory factor analysis (CFA), structural equation modeling (SEM) technique was used to test the hypothetical model. The Findings asserts that only two HRM practices (training and participation) and three transformational leadership components (vision, intellectual stimulation and personal recognition) have significant impacts on innovation. Besides, knowledge sharing has significant and positive impact on innovation.

Out of five HRM practices, training, staffing, participation have significant and positive impacts on knowledge sharing while intellectual stimulation, and personal recognition(as transformational leadership components) have significant and positive impacts.

Finally, knowledge sharing merely mediated the relationships of training, participation, vision and personal recognition with innovation.
\end{abstract}

Keywords: HRM practices, transformational leadership, knowledge sharing, innovation, electronic industry, Iran

\section{Introduction}

The subject of the effect of innovation on a firm's performance has been of interest to policy makers and economist for the past few decades according to Hashi and Stojci (2013). The innovation has infiltrated from the organizational level to the whole country. Countries can have a high growth rate and special trading terms by increasing products that of higher value through innovation (OECD/Eurostat, 2004).

Innovation can be defined as activities that involve technological, scientific, financial, commercial, and organizational components that would cause or intended to cause the execution of improved and scientifically new products (Hashi \& Stojci, 2013). Innovative ideas are influenced by a new thought by the action of an economic agent. An organization's efficiency is increased by the implementation of a new idea, which may cause an increase in the firm's production, and lower its cost of production compared to its competitors. Likewise, introducing new products services to consumers will cause the firm to expand into new areas in the market. Innovations allow an organization to distinguish itself from its competitors by introducing new improvements in products, operational processes and organization. $(\mathrm{Hu}, 2012)$ 
Innovation is an important component in the electronics industry especially if an organization is looking towards gaining a competitive advantage (Zohoori et al., 2013). Intel, for example, is known throughout the world for producing the chips that provide additional computing power to computers. The mobile phone industry is another interesting branch of the electronic industry. The competition from telecommunication terminal equipment company Ericsson plc.in Sweden gave rise to the innovative moves taken by Finnish company Nokia. Seo and Hwang (2012) defined it as the growth's initial factor. Prior to 1990, Finland was more famous for its cold lakes with the northern lights and reindeers and a country free of colonization from its neighbors in the Northern Europe region. Nevertheless, ever since 1998, Finland has become a leading country in the IT industry building globally recognized mobile companies such as Nokia known as one of the most innovative companies in the world (Seo \& Hwang, 2012).

The above examples highlight the need for innovation if a product in the electronic industry wants to be competitive and sustain its market share. It is clear that by increasing innovation, organizations can stay in the competition and be more successful.Therefore, this gives rise to the question what are the factors that can contribute to innovation performance in electronic industry.

Research on factors that contribute to innovation performance in organisations have found several factors such as organizational learning (García-Morales et al., 2007; Jiménez-Jiménez \& Sanz-Valle, 2011) and organizational commitment and job satisfaction (Low \& Mohammed, 2005; Morrow et al., 2012). However, research studies by Zohoori et al. (2013) and Asgharian et al. (2013) found that knowledge is the most important and influential factor on innovation in electronic industry because this industry is knowledge based industry. In addition, they proposed that one way of increasing the knowledge in the electronic industry and subsequently increasing innovation is through knowledge sharing.

Their insight about the importance of knowledge sharing for improving the innovation performance is consistent with the research findings by previous researchers (e.g. Dimitris et al., 2007; Wang et al., 2009; Chiang \& Hung, 2010; Wang \& Wang, 2012).

There are many highlighted factors from different scholars (e.g. Low \& Mohammed, 2005; Wang \& Noe, 2010; Wei et al., 2012; Asgharian et al., 2013) for increasing knowledge sharing culture. Some of these factors can be observed in either human resource management (HRM) practices or transformational leadership and can also be observed from the outcomes of both factors. For example staffing, training and reward are three HRM practices that have been identified by researchers as variables that can contribute toward knowledge sharing (Low \& Mohammed, 2005; Chen \& Huang, 2009; Fong et al., 2011). Transformational leadership has been found by other researchers (Childers, 2009; Liu et al., 2010) to significantly influence knowledge sharing in organizations.

One of the important topics in HRM is the HRM practices. There are so many different researches about the advantages of HRM practices within organisations. One of the most important advantages effective HRM practices is the improvement of organizational performance (e.g. Huselid, 1995). By assuming innovation as one of the organizational performance dimensions, it follows that HRM practices would impact innovation as well. This argument is consistent with the studies by Chen and Huang (2009) who investigated the effects of training, staffing, compensation, performance appraisal and participation on in decision making on innovation. From another point of view, HRM practices have the potential to impact knowledge sharing and innovation at the same time. In 2011, Fong et al. studied the relationship between HRM practices (training, staffing, teamwork, performance appraisal, and reward) and knowledge sharing as a gap in previous researches.

Transformational leadership is considered as another tool to partner with HRM practices, which can impact the employees behavior related to innovation, in a different way. One of the advantages of transformational leadership is that it empowers the employees to become followers (Maragh, 2011) which can lead to voluntary behaviors because of high levels of trust and motivation. For example, Wang et al. (2009) have studied the impact of transformational leadership on knowledge sharing and team innovation.

In Iran's 20-year vision to be achieved in 2025, there are several tasks that have been identified for the nation (Available at http://www.maslahat.ir/ - official website of Islamic Republic of Iran Expediency Council).The vision is to ensure that in 2025 , Iran will be a developed country by having an outstanding ranking in scientific, economical, and technological areas besides having a revolutionary Islamic identity and being the pioneer in encouraging the Islam world through effective and strategic international relationship and communication (Ahmadi et al., 2012).

In this vision, several characteristics have been identified for Iranian society which includes: 
- Achieving outstanding scientific capabilities in developing technology and knowledge, gained from a higher level of human capital and social assets in production nationally;

- Achieving the highest scientific, economic, and technological ranking in South West Asia, which includes Middle East, Caucasus, Central Asia, and countries in the neighbouring region, focusing on the development of software and scientific research, fast and sustainable progress in economy, and relative increase in the per capita income level in gaining full-employment (Moghaddam et al., 2011; Ahmadi et al., 2012; Moghaddam et al., 2012).

In order to achieve these objectives, $R \& D$ is a critical component. A successful R\&D endeavour encourages innovation domestically and the development of new technology (Ahmadi et al., 2012). In addition, it improves the capacity of the country to absorb new technology (Cohen, 1990; as cited in Ahmadi et al., 2012)

Currently the most important industries which are operating in Iran are petroleum, petrochemicals, fertilizers, caustic soda, textiles, cement and other construction materials, food processing (particularly sugar refining and vegetable oil production), ferrous and non-ferrous metal fabrication, and armaments. These industries have a key role in improving GDP and according to www.gfmag.com in 2012, 40.6\% of GDP growth was dependent to these industries. Another industry which has high potential for helping the economy of Iran is electronic industry.

Some studies (e.g. Asgharian et al., 2013; Zohoori et al., 2013) believe that the development in electronic industry of Iran can improve the economic condition of Iran in relation to achieving developmental objectives. Because of the fact that there is a high demand for electronic products, achieving advancement in electronic industry can be very useful.

The current status of this industry is unsatisfactory. It has not been able to reach the technical superiority required to compete internationally (Zohoori et al., 2013; Arzi et al., 2013).One cause attributed to this situation is the lack of innovation. (Asgharian et al., 2013; Zohoori et al., 2013; Arzi et al., 2013).

In the electronic industry, some countries such as USA and South Korea have invested heavily in R\&D which has resulted in increase of innovation. This has resulted in the development of new products and contributed to their success in the global market. The Iranian companies also trying to improve innovation in order to first penetrate the internal market and then compete with other companies in global markets (Asgharian et al., 2013).

The implementation of innovation relies heavily on the initiatives of the staff's expertise, commitment and knowledge as they play a major role in the value added processes (Youndt et al., 1996; Wang \& Wang, 2012; Zohoori et al., 2013). The perspective based on knowledge defines organizations as resources for competencies and knowledge (Grant, 1996; Spender, 1996). Based on this viewpoint, past studies have acknowledged the fact that the human capital's competencies and knowledge are priceless assets for the organizations as these characteristics are path-dependent, socially complex, and firm-specific (Lado \& Wilson, 1994; Youndt et al., 1996; Wright et al., 2001; Collins \& Clark, 2003; Wang \& Wang, 2012).

In line with the above argument, Asgharian et al. (2013) and Zohoori (2013) have explained that the required knowledge for improving electronic industry through innovation is dependent to increasing knowledge sharing and the subject based on SECI model (Nonaka \& Takeuchi, 1995) is acceptable. It means that knowledge sharing can lead to knowledge creation.

With respect to importance of knowledge sharing in increasing innovation, several researchers (e.g. Low \& Mohammed, 2005; Lin, 2007; Wang \& Noe, 2010; Wei et al., 2012) have tried to highlight main factors affecting knowledge sharing (culture, behavior, or process). Asgharian et al. (2013) conducted an exploratory research on 18 largest companies in electronics industry of Iran in order to highlight the main factors needed to increase knowledge sharing. In this regard, 9 factors highlighted by 122 managers (top and middle), are confidence, leaders' attitudes, performance evaluation, reward, training, recognition, staffing, emphasizing on innovation, and award. On the other hand, more than $83 \%$ of respondents believed that knowledge sharing reasons should be looked for in individual characteristics rather than groups' tendency. In addition, $92 \%$ of mangers stated that knowledge sharing should not be confined to R\&D departments.

Since there is a consensus among researchers that the electronic industry in Iran needs more innovation, and some experts believe that knowledge sharing could contribute towards innovation, therefore there is a need to be investigated the link between these two processes. Since HRM practice and transformational leadership style have been found to affect organizational behavior (Hamidifar, 2010; Fong et al., 2011), there is a very high likelihood that these two variables could influence knowledge sharing and innovation in organizations. However it is not clear whether these relationships holds true in the Iranian industry.

Although there are a lot of studies about increasing the knowledge sharing there is a still a gap that how 
employees involvement in decision making and giving value to their ideas can impact the increase of knowledge sharing. On the other hand, considering participation as one of the HRM practices will fill this gap in literature.

Even though previous studies (Lu et al., 2006; Wang et al., 2009; Lee et al., 2010) emphasize on the impact of transformational leadership on knowledge sharing and innovation, none of them clearly address the different components of transformational leadership. Therefore, investigating the impact of these components on both innovation and knowledge sharing can be known as another research gap in literature.

Additionally studying the impact of interaction among HRM practices and transformational leadership for improving knowledge sharing also can be another gap in previous researches. It is important to know which affective factors (on knowledge sharing) can be achieved by managing or leading. As mentioned in last section, various researchers have categorized factors affecting knowledge sharing into various groups. The classification of elements for knowledge sharing as HRM practices and transformational leadership will provide a new perspective. This perspective will consider the transformational leadership and HRM practices as influential on knowledge sharing and also complementary for each other.

According to twenty year vision for Iran, one of the proper approaches for penetration into global market is through electronic products. To do this there needs to be innovation in the industry. As a result of the ambiguity about the main factors that have the potential to influence innovation in Iran's electronic industry, a better understanding about the underlying factors is essential. Extant literature emphasized on a vital role of knowledge sharing in improving innovation, so this study tries to find how knowledge sharing could be increased by transformational leadership and HRM practices in electronic industry of Iran. More specifically the purpose study is "to determine the relationship between HRM practices and transformational leadership with knowledge sharing and innovation in the Iranian Electronic Industry."

\section{Literature Review}

In this part, the main aim is to highlight Human Resource Management concepts and Leadership concepts that are related to innovation aspects. In this regard, some other concepts, such as competitive advantage, intellectual capital, knowledge sharing, creativity, Resource based view (RBV), organizational performance and strategic jobs are discussed. As a result, the literature review will support to propose a new framework that links transformational leadership and human resource management practices to innovation directly and indirectly through knowledge sharing. Applying quantitative approach by famous scholars (e.g. Gumusluoglu and Ilsev, 2009; Wang et al., 2009; Chen and Huang, 2009; Fomg et al., 2011; Wei et al., 2012; Zohoori et al., 2013) has postulated that hypotheses testing can be efficient method to highlight the main influential factors on innovation and knowledge sharing. In the following, the hypotheses of this study will be developed based on the extant research.

\subsection{Innovation and Innovation Performance}

Innovation can be described as the process of transforming an idea into something that gains value in business. Companies that are innovative have learnt to recognize the need to have innovation as a requirement for business in terms of being repeatable, explicit, and a measurable business procedure (Runhua, 2011).

In the traditional comprehension of the innovation process, $R \& D$ has been known to play an active role. Investments in $R \& D$ are required to create and develop prototypes and to get a product to market fast (Freeman \& Soete, 1997; Saviotti \& Nooteboom, 2000). This R\&D innovation perspective has been questioned in various aspects. Firstly, innovation usually appears in a non-linear, complicated, and collaborative and using a process that is multi-level that is integrated in the innovation process (Lundvall, 1992). Secondly, in addition to R\&D and technology-based innovation, non-technological innovations are also beginning to gain recognition as a different path that can provide success to a firm (Totterdell et al., 2002; Piva \& Vivarelli, 2009).

Innovation also involves complicated tools of knowledge dissemination (Edquist, 1997) and can be driven by various innovative channels. Cassiman et al. (2010) differentiated these into and "Doing, Using, Interacting" and "Science, Technology and Innovation" approaches. The first approach depends more on the experience and process -based know-how while the second approach refers to conventional technological, usually driven by R\&D type of innovation. Given the various approaches to innovation and the interdependency of the processes of innovation and integration of the integration system, innovation can be described as a phenomenon that is diverse that takes place in high-tech firms, sectors and R\&D units. Robertson and Patel (2007) demonstrated that there is a close and reciprocal relationship between high, medium and low technology sectors among developed countries that is critical to the general growth of the economy.

Thus, the level of high, medium and low technology sectors' performance are very interdependent given the 
reciprocal scenario. The innovations carried out in high tech sector's trickle down to the low level in R\&D and the low and medium tech companies also become involved in the creation of knowledge in the high tech sectors (Robertson \& Patel, 2007).

More often than not innovation has been linked to activities derived from $R \& D$ and products as the innovative output. In the Schumpeterian-based comprehension, innovation is one way to reach the end; the end here as cited in financial gain, increased growth or competitive advantage (Schumpeter, 1934; as cited in Kirner et al., 2009).

In order to measure the innovation performance, researchers Chen and Huang (2009), used two approaches aspects namely technical innovation and administrative innovation. Technical innovation concentrated on creating new technologies, developing these technologies to make new products, and creating new processes that lower costs and develop quality. Administrative innovation involves the response to the environmental changes, process control system, integrated mechanisms, and planning procedures.

According to the scope of this study which concentrates on the electronic industry of Iran, it appears that this industry, initially, needs some improvements related to technical innovation in line with the result of studies conducted by Zohoori et al. (2013) and Arzi et al. (2013), as the current status of the mentioned industry is not satisfactory. In fact, this industry has insufficient ability to obtain superiority in technology in today's competitive environment. Therefore, this study concentrates on technical innovation as a necessity.

\subsection{Human Resource Management Practices and Innovation}

In current times, human resources (HR) have been considered an important element in achieving competitive advantage. Most of the empirical and theoretical research on human resources has been approached from the resource-based view (RBV) of the organization (Barney, 1986, 1991, 1995). The theory suggests that if organizations were to create a sustainable competitive advantage, they would have to have resources that are non-imitable, non-substitutable and rare. Many researchers such as Wright and McMahan (1992), Pfeffer (1994), Snell et al. (1996), and Barney $(1986,1991,1995)$ expounded on the fact that since resources that have always given organizations the competitive edge can be quickly and easily copied, human resources by far are the most important element for creating competitive advantage that can be sustained over time.

According to (Barney, 2001), resources can be described as "the tangible and intangible assets a firm uses to choose and implement its strategies". This general description involves organization, human, physical as well as financial resources. Based on Barney (1991) and Teece et al.'s (1997) research, they laid out a framework to decide on a resource that can be taken as a possible competitive advantage that can be sustained over time. The main features of the framework are that the resources should be non-imitable, non-substitutable, and rare.

Human Resource Management (HRM) practices can be described as the activities of the organization that involves the management of the group of human resources and making sure that their management is aligned to the goals of the organization (Wright \& Snell, 1991). Nevertheless, there are many interpretation of these practices based on different researchers and their areas of expertise in HR.

Several common HRM practices include performance evaluation, training, staffing, , compensation and reward system, and participation are linked to aspects such as lowering turnover, enhancing commitment, and improving performance via their effect on development and motivation of employees (Guthrie, 2001; Chen \& Huang, 2009). Therefore, this study also considers these five practices to continue and test the proposed framework.

In order for companies to introduce new products and develop new processes in management, they need the ability and motivation of their human capital to come up with ideas that are creative, approaches that are innovative, and present opportunities that are new (Scarbrough, 2003). The HRM function can change and have an effect on the capacities, attitudes, and behaviors of the workers to reach these objectives (Martinsons, 1995; Collins \& Clark, 2003; Chen \& Huang, 2009). This is an essential component in providing the appropriate environment for instigating and directing employees towards the development of activities that are innovative (Michie \& Sheehan, 1999; Laursen \& Foss, 2003; Scarbrough, 2003; Chen \& Huang, 2009). Companies are able to utilize HRM practices, that include recruitment, performance appraisal, training, and rewards to encourage commitment from the employees and to get them engaged in thinking and innovating creatively (Damanpour, 1991; Laursen \& Foss, 2003; Chen \& Huang, 2009).

Companies that utilize innovative characteristics and creative capabilities in recruitment and selection, the staff will be drawn to infuse ideas that are diverse and commit to further innovative actions (Atuahene-Gima, 1996; Brockbank, 1999; Chen \& Huang, 2009). Using an appropriate recruitment process, employees can emerge as critical avenues of new ideas in the organization's process of innovation. Training is another avenue that could enable employees to become exposed different types of knowledge and become willing to try out new ideas 
(Beatty \& Schneier, 1997; Brockbank, 1999; Jaw \& Liu, 2003; Chen \& Huang, 2009). Organizations could offer various broad training programs to employees to hone new skills, new knowledge, and necessary innovative abilities to carry out their work effectively (Brockbank, 1999; Mumford, 2000; Chun \& Huang, 2009).

(Weisberg, 2006) suggested that training can be used by firms to develop the firm's expertise in content and demand for innovation. Investments in training can develop employee expertise in the various departments in the firms which will probably cause an overflowing source to generate innovative ideas (Torraco \& Swanson, 1995; Chen \& Huang, 2009).

Organizations should place importance and value on innovation as a major priority in the firm and offer appraisal tools that are formal to calculate innovative actions and outcomes since the process of innovation process is usually long, tedious, complicated and involves various parties (Brockbank, 1999; Chen \& Huang, 2009). A performance appraisal that places positive pressure on employees can develop feelings of achievement and challenge and work as a great motivator for the workers (Jaw \& Liu, 2003; Chen \& Huang, 2009). Performance appraisals can improve the motivation of the employees to be involved in activities that are innovative, and cause the organizations to reach the objectives set out in the innovation process (Jiménez-Jiménez \& Sanz-Valle, 2005; Chen \& Huang, 2009). In addition, identifying team and individual achievements along with rewards would also inspire further innovation. Both intrinsic and extrinsic compensations are important to inspire workers to participate in work that is challenging and offer them benefits to come up with successful new products and create more new ideas (Brockbank, 1999; Mumford, 2000; Chen \& Huang, 2009).

Organizations that create innovative activities will face a comparatively higher level of variability and uncertainty in the process of innovation (Chen \& Huang, 2009; Atuahene-Gima, 1996). They require employees that are creative employees and are willing to be flexible, risk takers and tolerant of ambiguity and uncertainty (Chen \& Huang, 2009; Madsen \& Ulhøi, 2005). Hence, organizations must focus on these aspects during the recruitment process.

H1: HRM practices have a significant and positive effect on innovation

Sub hypotheses

H1a: Training has a significant and positive effect on innovation

H1b: Staffing has a significant and positive effect on innovation

H1c: Compensation and reward system have significant and positive effects on innovation

H1d: Performance Evaluation has a significant and positive effect on innovation

H1e: Participation has a significant and positive effect on innovation

\subsection{Transformational Leadership and Innovation}

Researchers have found that transformational leadership can accord better performance levels among employees by having an effect on their beliefs and objectives (Shao et al., 2012; Yukl, 2006). Rafferty and Griffin (2004) and Shao et al. (2012) presented 5 transformational leadership dimensions namely vision, personal recognition, inspirational communication, intellectual stimulation, and supportive leadership. This study has adopted these five dimensions for examination. The 5 sub-dimensions are defined in Table 1 below.

Table 1. Five sub-dimensions of transformational leadership

\begin{tabular}{ll}
\hline Sub-dimensions & Definitions \\
\hline $\begin{array}{l}\text { Inspirational } \\
\text { communication }\end{array}$ & $\begin{array}{l}\text { Indicating encouraging and positive messages regarding the firm, and motivating and } \\
\text { confidence building statements } \\
\text { Vision }\end{array}$ \\
$\begin{array}{l}\text { Visualizing an idealized future image of the organization and its values } \\
\text { Intellectual stimulation } \\
\text { Personal recognition }\end{array}$ & $\begin{array}{l}\text { Improving the staff's interest in and caring about problems, and improving their } \\
\text { Offering rewards such as acknowledgement and praise for initiative to achieve specified } \\
\text { objectives }\end{array}$ \\
Supportive leadership & Showing concern for employees and taking into account personal needs \\
\hline
\end{tabular}

Source: Griffin and Rafferty (2004) (as cited in Shao et al., 2012)

Transformational leaders tend to improve the level of innovation in the firms. These types of leaders utilize 
intellectual stimulation and inspirational motivation which is essential for innovation of the firm (Elkins \& Keller, 2003).

According to (Howell \& Higgins, 1990), transformational leaders encourage the flow of creative ideas in their firms; this action represents the role of championing which is customary transformational leadership (Howell \& Higgins, 1990). This leadership style encourages the leaders to have an objective that would inspire their followers, develop their engagement in performing at an outstanding level and challenges themselves to use innovative methods in their workplace. The heightened level of motivation will result in having an improved level of innovation in the organization (Mumford et al., 2002). Several empirical researches have proven that these types of leaders have a positive effect on innovation in the firms (Waldman \& Atwater, 1994; Keller, 1992).

Transformational leaders stimulate their followers intellectually stimulating, champion innovation, and provide a strong vision within their firms, assist in cultivating an organization-wide climate where the workers are energized and challenged to find approaches that are innovative in their job functions (Gumusluoglu \& Ilsev, 2009). Consequently, the following hypothesis is proposed:

H2: Transformational leadership has a significant effect on innovation

Sub hypotheses

H2a: Inspirational communication has a significant and positive effect on innovation

$\mathrm{H} 2 \mathrm{~b}$ : Vision has a significant and positive effect on innovation

H2c: Intellectual stimulation and reward system have significant and positive effects on innovation

H2d: Personal recognition has a significant and positive effect on innovation

H2e: Supportive leadership has a significant and positive effect on innovation.

\subsection{HRM Practices and Knowledge Sharing}

It is critical that organizations choose staffs that are able to integrate successfully in improving the capacity for knowledge management. Choosing the right candidate with the right attitude and skill set to carry out the job functions allows the organizations to converge knowledge from various sources and instigate and generate innovative ideas (Scarbrough, 2003; Martinsons, 1995). Furthermore, staff training also has an effect on the enhancement of capacity for knowledge management. Continuous professional learning is especially critical for knowledge workers to improve. Organizations are required to provide training opportunities both within the firm and external workshops to nurture and develop expertise and knowledge in the staff (Nonaka \& Takeuchi, 1995; Brockbank, 1999; Jaw \& Liu, 2003; Chen \& Huang, 2009).

According to (Nonaka \& Takeuchi, 1995), being exposed to a variety of trainings would enhance the staff's expertise and gain new knowledge, wide their understanding and provide them with innovative skills and mindsets. These training programs would encourage the staff to relate to others their experience and expertise, gain knowledge that is new, and apply the new ideas for the work purposes. Consequently, training is essential for knowledge management process among employees (Von Krogh, 1998; Argote et al., 2003; Chen \& Huang, 2009).

Participation is another aspect of HRM practice that would motivate employees to be involved positively and share in the activities of learning and knowledge management. Employees who have a wide range of expertise, skills and obligations should provide a higher level of self-regulation and autonomy in the jobs (Nonaka \& Takeuchi, 1995). Allowing a higher level of participation and discretion in making decisions can improve the awareness, involvement, and commitment of the employees (Damanpour, 1991; Glynn, 1996). When employees have access to more opportunities to offer their ideas and opinions and state the necessary actions, they will improve their diversity and vast knowledge and contribute further (Grant, 1996; Andrews \& Kacmar, 2001; Chen \& Huang, 2009) which will in turn facilitate the utilization and discovery of scattered expertise and knowledge in the firms.

Compensations and Performance appraisals are the main HRM practices that organizations utilize to strengthen the behaviors of employees' and persuade them to reach the organizational objectives (Scarbrough, 2003; Collins \& Clark, 2003). When organizations wish to bring out the expected behaviors from their workers, they must offer incentives and feedback that would further strengthen the expected desired behaviors and this is usually carried out during the performance appraisal (Collins \& Clark, 2003).

According to (Currie \& Kerrin, 2003), employees would probably not be involved in knowledge management activities, particularly in knowledge sharing since it would be contrary to the goals in their performance forms. 
Consequently, if organizations establish a standardized appraisal guideline to relate the performance of the employees with their participation in applying and sharing knowledge at the workplace, it would inspire the employees to become engaged in KM activities. In addition, the compensation should recognize and offer rewards for risk-taking attitude, creativity, and the ability to solve problems to stimulate knowledge sharing and diffusion (Von Krogh, 1998; Argote et al., 2003; Chen \& Huang, 2009). Employees would place more importance on knowledge management activities if the rewards systems recognized and acknowledges their contributions in the exchange and acquisition of knowledge (Von Krogh, 1998; Scarbrough, 2003; Collins \& Clark, 2003).

Based on the research of Low and Mohammed (2005), Wang and Noe (2010), and Wei et al. (2012), Asgharian et al. conducted a research on 18 largest companies in electronics industry of Iran in order to highlight the main factors needed to increase knowledge sharing culture. In this regard, 9 factors were highlighted by 122 managers (top and middle), these are: trust and confidence, leaders' attitudes, performance evaluation, reward, training, recognition, staffing, emphasizing on innovation, and Award. Some of the factors can be considered as HRM practices, for example reward, performance evaluation, staffing and training.

Although it seems that the number of studies about the relationship of HRM practices and knowledge sharing is not that many, most of the recognized factors by different studies have indirectly shown the important role of HRM practices. For example, Dyer and Nobeoka (2002) studied the role of training on increasing knowledge sharing in Toyota. Low and Mohammed (2005) also focused on training as one of the learning components.

As a gap in the previous studies, Fong et al. (2011) considered HRM practices (compensation, training, staffing, performance appraisal, and team work) as influential factors on knowledge sharing. Nonetheless, there is still a gap on how employee's involvement in decision making and giving value to their ideas can impact the increase of knowledge sharing. On the other hand, considering participation as one of the HRM practices will bridge this gap in literature.

H3: HRM practices have a significant and positive effect on knowledge sharing

Sub hypotheses

H3a: Training has a significant and positive effect on knowledge sharing

H3b: Staffing has a significant and positive effect on knowledge sharing

H3c: Compensation and reward system have significant and positive effects on knowledge sharing

H3d: Evaluation performance has a significant and positive effect on knowledge sharing

H3e: Participation has a significant and positive effect on knowledge sharing

\subsection{Transformational Leadership and Knowledge Sharing}

The other factors explored by Asgharian et al. (2013) can be considered as highly close to concepts such as leadership style, which will be explained in detail in the following sections. However, in improving on past studies, Low and Mohammed (2005) believed that trust and confidence have a significant relationship with leadership style. In addition, Asgharian et al. (2013) understood that trust and confidence could impact knowledge sharing. Therefore, it can be concluded that transformational leadership can influence knowledge sharing because many researches (e.g. Gillespie \& Mann, 2004; Liu et al., 2010) have shown that transformational leadership can increase trust.

Another subject is the effect of transformational leadership on motivation. As it will be discussed later, transformational leadership can act as a motivational factor. For example, Gumusluoglu and Ilsev (2009) use transformational leadership as a motivational factor for innovation and creativity. Hence, in a similar way, it can be employed as a motivational factor for increasing knowledge sharing.

Wang et al. (2009), investigated the existence of relationship among different kinds of leadership style (transactional leadership, authoritarian leadership, benevolent leadership and transformational leadership) and knowledge sharing and their results show that only the influence of transformational leadership and benevolent leadership are positive and significant.

Past researches such as Lu et al. 2006 proposed that the leadership style has a critical effect on the ability, choice, and motivation to share knowledge (Wang et al., 2009). Leaders can provide further stimulus towards knowledge management by motivating and facilitating experimentation and knowledge sharing by trust, coaching, and empowerment (Haas \& Hansen, 2005).

In addition, Wang et al. (2009) discovered that in China, transformational leadership improved communication 
and knowledge sharing in foreign-invested firms, state-owned firms, and privately owned firms.

Given the above argument and the critical role of motivation in knowledge sharing, it can be surmised that transformational leadership has the ability to improve and enhance the need for knowledge sharing among staff in a firm. This leads to the following hypothesis:

H4: Transformational leadership has a significant effect on knowledge sharing

Sub hypotheses

H4a: Inspirational communication has a significant and positive effect on knowledge sharing

$\mathrm{H} 4 \mathrm{~b}$ : Vision has a significant and positive effect on knowledge sharing

H4c: Intellectual stimulation and reward system have significant and positive effects on knowledge sharing

H4d: Personal recognition has a significant and positive effect on knowledge sharing

H4e: Supportive leadership has a significant and positive effect on knowledge sharing

\subsection{Knowledge Sharing and Innovation}

According to Moorman and Miner, 1998, knowledge sharing can be defined as a set of behavioral practices or beliefs that are associated to the expansion of learning among various individuals or groups in a firm. Researchers such as Shao et al. 2012 divided knowledge into 2 dimensions namely explicit and tacit knowledge sharing. This study will also adopt these two dimensions.

Past studies have argued about the effectiveness of knowledge sharing causing an improved level of innovation within the organization (Kogut \& Zander, 1992; Henderson \& Cockburn, 1994; Szulanski, 1996; Tsai \& Ghoshal, 1998; Dyer \& Nobeoka, 2000; Tsai, 2002; Chen \& Huang, 2009). Specifically, researchers have pointed out that in the past knowledge sharing construed the new integration of knowledge that existed on its own, which would possibly end up in novel products or process improvements (Tsai \& Ghoshal, 1998; as cited in Chen \& Huang, 2009).

Considering the fact that knowledge is present in various employees and departments within the firm, the employees are required to share this knowledge to set up new mental models and practices (Nonaka \& Takeuchi, 1995; Galunic \& Rodan, 1998; Chen \& Huang, 2009). Innovations are apparent when employees use their technical know-how and transform it into explicit knowledge resulting in new products (Nonaka \& Konno, 1998; Chen \& Huang 2009). Therefore, organizations that share knowledge effectively with each other in the work place have a better chance of being more innovative (Chen \& Huang, 2009).

Even though, the findings were not conclusive as to the relationship between innovation and knowledge sharing, Wang et al. (2009) investigated this association further.

On the other hand, Asgharian et al. (2013) found individual factors as an important reason of weakness in knowledge sharing of electronic industry of Iran. In this regard, this study will apply two dimensions defined by Van Den Hoof and De Ridder (2004). They defined two facets; collecting/receiving and donating/disseminating. Knowledge donating is defined as "communication based upon and individual's own wish to transfer intellectual capital". Knowledge collecting is "attempting to persuade others to share what they know".

Besides, Lin (2007) asserted that these dimension can measure knowledge sharing behaviors properly. Consequently, this study also considers these dimensions, and based on the researches' perspectives, will attempt to test the following hypothesis:

H5: Knowledge sharing has a significant effect on innovation

According to the explained relations and the developed hypotheses, this study will define two more hypotheses as well. These two hypotheses ( $\mathrm{H} 6$ and $\mathrm{H} 7$ ) have been focused on mediating role of knowledge sharing.

H6: Knowledge sharing mediates the relationship between HRM practices and innovation

Sub hypotheses

H6a: Knowledge sharing mediates the relationship between training and innovation

H6b: Knowledge sharing mediates the relationship between staffing and innovation

H6c: Knowledge sharing mediates the relationship between compensation and reward system and innovation

H6d: Knowledge sharing mediates the relationship between evaluation and innovation

H6e: Knowledge sharing mediates the relationship between participation and innovation 
H7: Knowledge sharing mediates the relationship between transformational leadership and innovation

Sub hypotheses

H7a: Knowledge sharing mediates the relationship between inspirational communication and innovation

H7b: Knowledge sharing mediates the relationship between vision and innovation

H7c: Knowledge sharing mediates the relationship between intellectual stimulation and reward system and innovation

H7d: Knowledge sharing mediates the relationship between and personal recognition innovation

H7e: Knowledge sharing mediates the relationship between supportive leadership and innovation

\section{Method and Results}

The 4 key constructs that were identified were measured using 88 structured questions. Each question in the questionnaire emphasizes specifically on a particular factor and questions are brief and clear. A structured questionnaire was utilized to make sure that there was standardization in the response given and in the gathering of data. A set of structured questionnaire consists of questions where respondents choose from a set of fixed response choices. The questionnaire includes issues related to the background of respondents, possible determinants that directly or indirectly affect the innovation. Likert five-point scales that ranges from "strongly disagree" to "strongly agree" are used in the questionnaire.

The items related HRM practices were adapted from Chen and Huang (2009) and Masood (2010). Knowledge sharing was measured based on the two main dimensions as knowledge donating and collecting proposed by Alhady et al. (2011); Lin (2007). Research conducted by Rafferty and Griffin (2004) and Shao et al. (2012) were applied to adapt and develop transformational leadership's items. To measure the technical innovation, the research of Chen and Huang (2009) were applied.

Table 2. Respondents' profile

\begin{tabular}{lll}
\hline & Frequency & Percentage \\
\hline Gender & 266 & 69.6 \\
Male & 116 & 30.4 \\
Female & & \\
Age & 60 & 15.7 \\
less than 20 & 92 & 24.1 \\
$\mathbf{2 1 - 3 0}$ & 83 & 21.7 \\
$\mathbf{3 1 - 4 0}$ & 87 & 22.8 \\
$\mathbf{4 1 - 5 0}$ & 60 & 15.7 \\
more than 51 & & \\
Experience & 23 & 6.0 \\
less than 5 & 69 & 18.1 \\
6-10 & 145 & 38.0 \\
11-15 & 114 & 29.8 \\
$\mathbf{1 6 - 2 0}$ & 31 & 8.1 \\
more than 21 & & \\
Qualification & 55 & 14.4 \\
Diploma & 70 & 18.3 \\
Bachelor & 156 & 40.8 \\
Master & 101 & 26.4 \\
Doctorate & & \\
Position & 117 & 30.6 \\
Manager & 65 & 17.0 \\
Technician & 165 & 43.2 \\
Engineer & 35 & 9.2 \\
Others & & \\
\hline
\end{tabular}


The population assigned for this research was experts and educated managers and engineers who are employed in electronic companies in Iran. As previous highlighted, this study is concentrated on 8 largest companies. Based on the results of the research of Asgharian et al. (2013), 92\% of managers voted to knowledge sharing not only in R\&D departments. This case resulted in the fact that this study chose respondents outside of its own $R \& D$ department such as employees who are engineers, expert technicians, and foremen on top of managers.

The chosen sampling method for this research was stratified random sampling. This type of sampling method is considered as the most proper method as stratified random sampling creates heterogeneity between participants that can reduce the usual survey errors (Bryman, 2012).

The process of survey started from June 2013 and finished in August 2013. There were 430 distributed questionnaires. The total collected questionnaires were 382 from 430 questionnaires because the observations with missing data of the analyses were excluded from the study. There were 6 questionnaires which were excluded because they were outlier from 382 . Therefore, for the analyses a total of 376 returns were used. The net of response rate was $87.44 \%$.

The aspects of the sample related to the respondent's profiles are described (see Table 2).

According to the developed table related to the constructs' measure and descriptive analysis (See Appendix), all of the items have the acceptable skwness and kurtosis. It should be noted that the positive sign for Kurtosis insists that peaks are focused to the right side and the negative signatures for the rest of the values demonstrate the peaks which are focused to the left. Also, all of the values related to Kurtosis have negative signatures that represent the distribution which is flat.

For having data reduction, there were some conducted exploratory factors analyses (EFA) for the HRM and Transformational leadership that led to some acceptable results for the KMO. It should be mentioned that some of the questions were not removed (See Appendix).

After confirmatory factor analysis (CFA) for each construct (to achieve acceptable fit indices), reliability and validity of the constructs was tested.

At first the reliability of the measures in the thesis was evaluated by Cronbach's (1951) coefficient alpha and next confirmatory factor analyses was used, for the Cronbach's coefficient alpha, convergent validity table (see appendix) demonstrates that all of the constructs pass the level of .70 which was suggested (Nunnally, 1978). In usage of confirmatory factor analyses AVE (average shared variance) and CR (composite reliability) were computed from model by means of CR formula and also AVE formula developed by Fornell and Larcker (1981). Bagozzi and Yi (1988) suggested that CR must be higher than or equal to .60 and also AVE must be higher than or equal to .50 . According to these calculations, the used measures inside the paper were inside the good levels which supported the constructs reliability. As a result, all the elements contained high loading (more than .50) were significant.

At last, the discriminate validity was evaluated by means of Kline method in 2005. Taking Kline (2005) statements that the estimated correlation among elements should not be more than .85 and each model of measurement was related to this evaluation. In this research none of the influential factors on knowledge sharing had the correlation above .85 (See Table 3).

Table 3. Discriminate validity

\begin{tabular}{lllllllllll}
\hline Observed variables & 1 & 2 & 3 & 4 & 5 & 6 & 7 & 8 & 9 & 10 \\
\hline 1 (Training) & $\mathbf{. 6 1 1}$ & .119 & .430 & .275 & .089 & .17 & .189 & .0008 & .066 & .0009 \\
2 (Staffing) & .346 & $\mathbf{. 6 5 6}$ & .318 & .495 & .069 & .298 & .508 & .548 & .045 & .060 \\
3 (Appraisal) & .656 & .564 & $\mathbf{. 5 9 5}$ & .276 & .322 & .239 & .490 & .131 & .016 & .056 \\
4 (Compensation) & .525 & .704 & .526 & $\mathbf{. 6 5 0}$ & .220 & .550 & .322 & .521 & .139 & .209 \\
5 (Participation) & .299 & .264 & .568 & .470 & .737 & .273 & .505 & .242 & .001 & .108 \\
6 (Vision) & .130 & .546 & .489 & .742 & .523 & $\mathbf{. 9 2 0}$ & .583 & .227 & .0056 & .163 \\
7(Inspirational Comm.) & .435 & .713 & .700 & .568 & .711 & .764 & $\mathbf{0 . 6 2 7}$ & .454 & .025 & 0.18 \\
8(Intellectual Stim.) & .028 & .274 & .363 & .722 & .492 & .477 & .674 &. $\mathbf{7 2 8}$ & .033 & .555 \\
9(Personal Recog.) & .257 & .212 & .127 & .373 & .010 & -.075 & .161 & -.183 &. $\mathbf{7 9 4}$ & .029 \\
10(Supportive Lead.) & -.031 & .246 & .238 & .458 & .329 & .404 & .425 & .745 & -.173 & $\mathbf{. 6 8 2}$ \\
\hline
\end{tabular}


Table 4. Fit indices of overall model

\begin{tabular}{llll}
\hline Fit Measure & Recommended Value & Primary Results & Final results \\
\hline Df & & 1356 & 1204 \\
Chi-square $\left(\chi^{2}\right)$ & & 4932.89 & 3905.73 \\
$\mathrm{p}$-value & $\mathrm{P}>0.05$ & 0.00 & 0.112 \\
$\chi^{2} / \mathrm{df}$ & Between 1and 5 & 3.637 & 3.243 \\
$\mathrm{GFI}$ & 0.90 or higher & 0.884 & 0.906 \\
AGFI & 0.90 or higher & 0.896 & 0.943 \\
NFI & 0.90 or higher & 0.851 & 0.939 \\
CFI & 0.90 or higher & 0.845 & 0.977 \\
TLI & 0.90 or higher & 0.890 & 0.963 \\
RMSEA & Between 0.05 and 0.08 & 0.081 & 0.075 \\
\hline
\end{tabular}

Table 5. Results of hypotheses testing

\begin{tabular}{|c|c|c|c|c|c|}
\hline Hypothesis & $\begin{array}{l}\text { Expected } \\
\text { Sign }\end{array}$ & $\begin{array}{l}\text { Standardized } \\
\text { Estimate }\end{array}$ & $\begin{array}{l}\text { Z-value } \\
(\mathrm{CR}>1.96)\end{array}$ & P-value & Supported \\
\hline H1a: Training $\rightarrow$ innovation & + & .407 & 23.44 & .000 & Yes \\
\hline H1b: Staffing $\rightarrow$ innovation & + & -.104 & -.023 & 1.01 & No \\
\hline H1c: Compensation $\rightarrow$ innovation & + & .032 & -1.34 & .710 & No \\
\hline H1d: Appraisal $\rightarrow$ innovation & + & .028 & 1.39 & .089 & No \\
\hline H1e: Participation $\rightarrow$ innovation & + & .365 & 21.21 & .001 & Yes \\
\hline $\begin{array}{l}\text { H2a: Inspirational communication } \rightarrow \\
\text { innovation }\end{array}$ & + & -.104 & -2.34 & .221 & No \\
\hline $\mathrm{H} 2 \mathrm{~b}:$ Vision $\rightarrow$ innovation & + & .239 & 4.76 & .049 & Yes \\
\hline $\begin{array}{l}\text { H2c: Intellectual stimulation } \rightarrow \\
\text { innovation }\end{array}$ & + & .347 & 11.23 & .012 & Yes \\
\hline $\begin{array}{l}\text { H2d: Personal recognition } \rightarrow \\
\text { innovation }\end{array}$ & + & .199 & 65.24 & .000 & Yes \\
\hline $\begin{array}{l}\text { H2e: Supportive leadership } \rightarrow \\
\text { innovation }\end{array}$ & + & .035 & 1.44 & .752 & No \\
\hline H3a: Training $\rightarrow$ knowledge sharing & + & .484 & 29.89 & .009 & Yes \\
\hline H3b: Staffing $\rightarrow$ knowledge sharing & + & .231 & 27.91 & .024 & Yes \\
\hline $\begin{array}{l}\text { H3c: Compensation } \rightarrow \text { knowledge } \\
\text { sharing }\end{array}$ & + & .087 & .021 & .123 & No \\
\hline H3d: Appraisal $\rightarrow$ knowledge sharing & + & .096 & 1.08 & .072 & No \\
\hline $\begin{array}{l}\text { H3e: } \\
\text { sharing }\end{array}$ & + & .564 & 41.20 & .000 & Yes \\
\hline $\begin{array}{l}\text { H4a: Inspirational communication } \rightarrow \\
\text { knowledge sharing }\end{array}$ & + & .011 & .315 & .265 & No \\
\hline H4b: Vision $\rightarrow$ knowledge sharing & + & .605 & 19.09 & .000 & Yes \\
\hline $\begin{array}{l}\text { H4c: Intellectual stimulation } \rightarrow \\
\text { knowledge sharing }\end{array}$ & + & .347 & 12.65 & .016 & Yes \\
\hline $\begin{array}{l}\text { H4d: Personal recognition } \\
\text { knowledge sharing }\end{array}$ & + & .444 & 17.44 & .010 & Yes \\
\hline $\begin{array}{l}\text { H4e: Supportive } \\
\text { knowledge sharing }\end{array}$ & + & .104 & 1.86 & .099 & No \\
\hline H5: Knowledge sharing $\rightarrow$ innovation & + & .503 & 22.702 & 000 & Yes \\
\hline
\end{tabular}




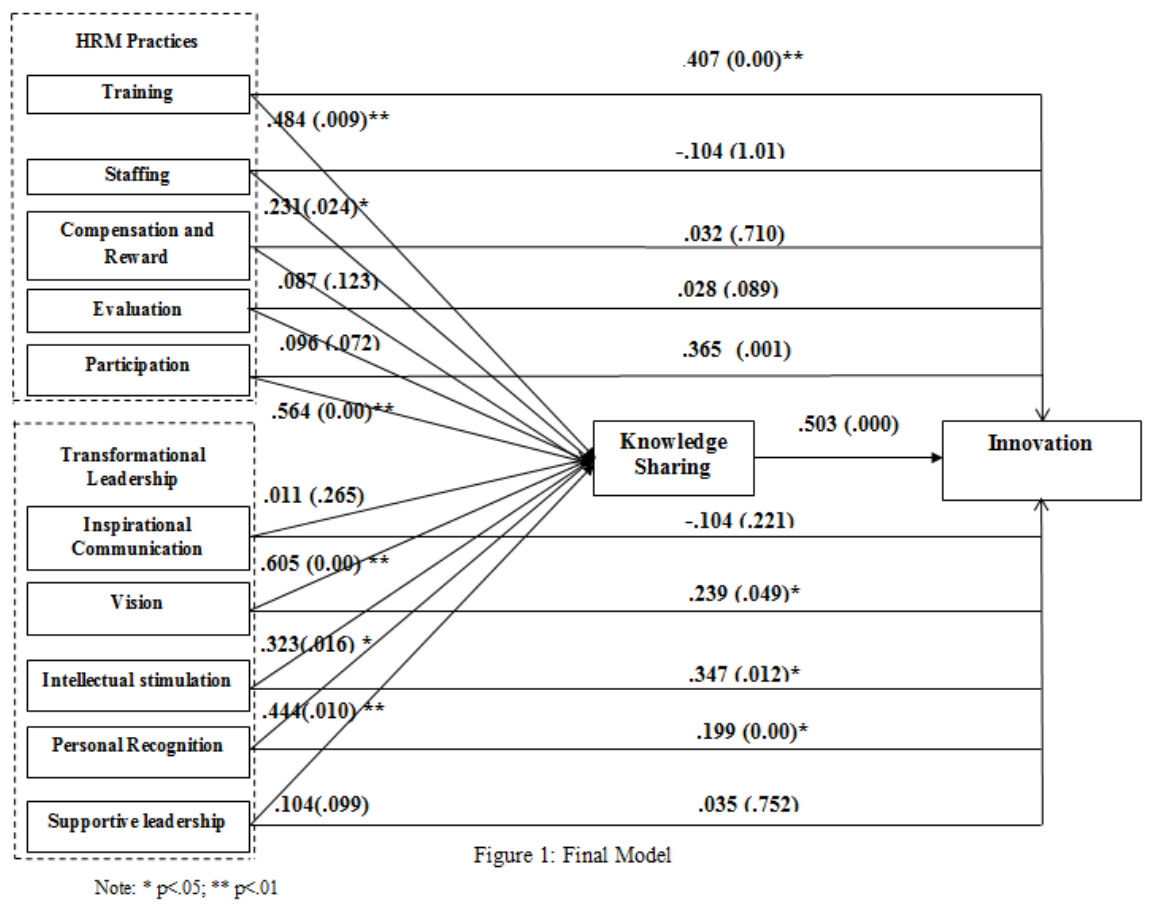

Figure 1. Shows the p-values and estimated regression weigh of each relationship in the proposed framework of study

Also the convergent validity was supported by AVE to be .50 and above. Moreover, the model to be fit by goodness of fit indicators has verified the validity of construct. Discriminate validity was obtained by reviewing the correlation among each of two construct minus innovation and knowledge sharing.

As a key rule, in 2006 Hair et al. noted that AVE is better to be more than the squared correlations. In Table 3, the numbers below the bold number show the correlation among variables and the numbers above the bold number mention the R-square between the variables.

For assessing the whole structure model we developed the CFA for the total structural model. It means that after obtaining the measurement model which was satisfactory we can evaluate the whole structure model. Anyway, the final evaluation of structural model was defined by investigating all the criteria for fit and the model as well specified again till getting an acceptable fit. The Table 4 demonstrates the results before and after fitting the model.

In the next stage, structural equation modeling (SEM) was applied in order to test the hypotheses. According to Table 5 and Table 8 there are two groups of hypotheses in this research. The first category is related to impacts of exogenous construct on endogenous construct. The second category was mentioning the mediating role of knowledge sharing on relationship between HRM practices and transformational leadership with the innovation.

The research relates to the Baron and Kenny's (1986) study for analyzing the mediating impact of knowledge sharing among transformational leadership and HRM practices with the innovation.

For this reason, for all of the HRM practices components and transformational leadership there will be three models to be measured. In first model, the impact of IV on Meditor will be measured. In the second model, the mediator will be removed and the impact of independent variable on dependent variable will be measured. In the third model the effect of IV on DV will be measured by considering the mediator which exists (see Table 6). It means that in the fourth step there will be mediator and knowledge sharing in models for examining if it declines the impact of the antecedents to non-significance. For this purpose, we will use the z-value indicator in Sobel test which should be more than 1.96 or less than -1.96. (Sobel, 1986).

Table 6 shows the fit indices of each model. Based on the results, all models are in acceptable fitness.

In the Table 7 all of the outcomes about the review of hypotheses could be seen that are related to mediating role of the knowledge sharing. 
Table 6. Goodness-of-fit indices for the structural model

\begin{tabular}{lllll}
\hline Fit Measure & Recommended Value & Model 1 & Model 2 & Model 3 \\
\hline Df & & 1002 & 1151 & 1204 \\
Chi-square $\left(\chi^{2}\right)$ & & 2390.7 & 3032.21 & 3905.73 \\
p-value & $\mathrm{P}>0.05$ & .121 & 0.108 & 0.112 \\
$\chi^{2} / \mathrm{df}$ & Between 1 and 5 & 2.385 & 2.634 & 3.243 \\
GFI & 0.90 or higher & .921 & 0.905 & 0.906 \\
AGFI & 0.90 or higher & .961 & 0.951 & 0.943 \\
NFI & 0.90 or higher & 0.944 & 0.921 & 0.939 \\
CFI & 0.90 or higher & 0.943 & 0.980 & 0.977 \\
TLI & 0.90 or higher & 0.963 & 0.971 & 0.963 \\
RMSEA & Between 0.05 and 0.08 & 0.055 & 0.063 & 0.075 \\
\hline
\end{tabular}

According to the obtained results from analyzing all of the 3 mentioned models, mediating role for the knowledge sharing was accepted only for participation, training, vision as well as personal recognition. This fact according to the amounts of z-value will be resulted. Hence, the rest of the results from testing the hypotheses are demonstrated in Table 8.

Table 7. Test of mediating role of knowledge sharing

\begin{tabular}{|c|c|c|c|c|}
\hline Variables & $\begin{array}{l}\text { Estimated } \\
\text { Coefficient of } \\
\text { Model 1 } \\
(\mathrm{IV} \rightarrow \text { Mediator) }\end{array}$ & $\begin{array}{l}\text { Estimated } \\
\text { Coefficient of } \\
\text { Model } 2 \\
(\mathrm{IV} \rightarrow \mathrm{DV})\end{array}$ & $\begin{array}{l}\text { Estimated Coefficient } \\
\text { of Model } 3 \\
\text { (IV } \rightarrow \text { DV, and } \\
\text { mediator controlled) }\end{array}$ & $\begin{array}{l}\text { Z-value } \\
\text { (By Sobel Test) }\end{array}$ \\
\hline Training & $.484^{* *}$ & $.651^{* *}$ & $.407^{* *}$ & $6.92^{* *}$ \\
\hline Staffing & $.231^{* *}$ & .012 & -.104 & 1.01 \\
\hline Compensation & .087 & .076 & .032 & .710 \\
\hline Appraisal & .096 & .077 & .028 & .089 \\
\hline Participation & $.564^{* *}$ & $.649^{* *}$ & $.365^{* *}$ & $5.710^{* *}$ \\
\hline $\begin{array}{l}\text { Inspirational } \\
\text { communication }\end{array}$ & .011 & -.098 & -.103 & -.091 \\
\hline Vision & $.605^{* *}$ & $.544^{* *}$ & $.239^{* *}$ & $4.63^{* *}$ \\
\hline Intellectual stimulation & $.323^{* *}$ & $.361^{* *}$ & $.199^{* *}$ & 1.751 \\
\hline Personal recognition & $.444^{* *}$ & $.573^{* *}$ & $.349^{* *}$ & $5.499^{* *}$ \\
\hline Supportive leadership & .104 & .017 & .035 & .652 \\
\hline Knowledge Sharing & Nil & Nil & $.503^{* *}$ & Nil \\
\hline
\end{tabular}

Note: $* \mathrm{p}<.05 ; * * \mathrm{p}<.01$

Table 8. Hypotheses testing related to the mediating role of knowledge sharing

\begin{tabular}{ll}
\hline Hypotheses & Supported \\
\hline $\mathrm{H} 6 \mathrm{a}:$ Training $\rightarrow \mathrm{KS} \rightarrow$ Innovation & Yes \\
$\mathrm{H} 6 \mathrm{~b}:$ Staffing $\rightarrow \mathrm{KS} \rightarrow \mathrm{Innovation}$ & No \\
$\mathrm{H} 6 \mathrm{c}:$ Compensation $\rightarrow \mathrm{KS} \rightarrow$ Innovation & No \\
$\mathrm{H} 6 \mathrm{~d}:$ Appraisal $\rightarrow \mathrm{KS} \rightarrow$ Innovation & No \\
$\mathrm{H} 6 \mathrm{e}:$ Participation $\rightarrow \mathrm{KS} \rightarrow$ Innovation & Yes \\
$\mathrm{H} 7 \mathrm{a}:$ Inspirational communication $\rightarrow \mathrm{KS} \rightarrow$ Innovation & No \\
$\mathrm{H} 7 \mathrm{~b}:$ Vision $\rightarrow \mathrm{KS} \rightarrow$ Innovation & Yes \\
$\mathrm{H} 7 \mathrm{c}:$ Intellectual stimulation $\rightarrow \mathrm{KS} \rightarrow$ Innovation & No \\
$\mathrm{H} 7 \mathrm{~d}:$ Personal recognition $\rightarrow \mathrm{KS} \rightarrow$ Innovation & Yes \\
$\mathrm{H} 7 \mathrm{e}:$ Personal recognition $\rightarrow \mathrm{KS} \rightarrow$ Innovation & No \\
\hline
\end{tabular}


According to the achieved results, H6a, H6e, H7b, and H7d are supported by this study. On the other hand H6b, $\mathrm{H} 6 \mathrm{c}, \mathrm{H} 6 \mathrm{~d}, \mathrm{H7a}, \mathrm{H} 7 \mathrm{c}$, and $\mathrm{H7e}$ are rejected.

\section{Discussion}

According to the Table 5, we are $95 \%$ confident that the impact of training on innovation is significant. The obtained results are consistent with previous studies by Chen and Huang (2009).

Staffing does not have a crucial role in the electronic industry of Iran for increasing technical innovation because the p-value 1.01 is more than .05. This result is in contrary to previous studies by Cabera and Cabera (2005), and Chen and Huang (2009). Although staffing is important in knowledge based companies, this study has achieved a totally different outcome. Perhaps the reason is that the companies in Iran do not demand the employment of expert and knowledgeable workforce.

Because of the estimated p-value compensation does not have a significant impact on technical innovation. The result is in contrary to previous studies by Chen and Huang (2009) and Fong et al. (2011). As such, we cannot consider compensation as an influential factor on technical innovation in the electronic industry of Iran.

Based on the gathered outcomes from Table 5, the impact of performance evaluation or on technical innovation is not significant because p- value is equal to .089 , which is greater than .05 . The result is consistent with the studies conducted by Chen and Huang (2009). On the other hand, in 2006, Chen et al. noted that performance appraisal has a positive and significant impact on innovation, which opposes the result of this research. Finally, performance evaluation cannot be assumed as an influential factor on technical innovation in the electronic industry of Iran.

The p-value of impact of the participation on innovation is .001, thus, this impact is significant. The previous studies by Baldwin and Gu (2004) and Chen and Huang (2009) also showed similar results, which demonstrate the importance of participation.

Previous researchers (Gumsluoglu \& Ilsev, 2009; Wang et al., 2009) show that transformational leadership is important for increasing knowledge sharing or innovation. However, there is not any specific concentration on any dimension. Therefore, any result relevant to the existing relationship between innovation and these dimensions could be assumed as a new outcome. Based on the obtained results, expects inspirational communication and supportive leadership, other components have significant impacts on innovation.

As it was expected, the impact of training on knowledge sharing in this study is positive and significant. According to the obtained results in Table 6, $\mathrm{p}$ value is .009 . The result is consistent with past studies by Low and Mohammed (2005). Any kind of training for management and engineers can be influential for knowledge sharing. In a developed study by Fong et al. (2011), the impact of training on knowledge sharing was significant. Therefore, we can advance the level of knowledge sharing through training.

Staffing is known as the acquiring process and also deploying and the retraining of the workforce with proper quality and quantity for developing positive influences on the effectiveness of the organization. Based on the results in Table 5, the staffing impact on knowledge sharing is significant because p-value is .024. The results of this study are consistent with previous studies by Fong et al. (2011) and Asgharian et al. (2013). Therefore, any improvement in staffing can lead to the increase of knowledge sharing. By employing the proper individuals in a right position, we can increase the knowledge sharing culture in the electronic industry of Iran.

The impact of compensation on knowledge sharing is not significant because p-value is .123 and more than .05. In addition, in 2012, Wei et al., found that the impact of extrinsic and intrinsic rewards have a significant impact on knowledge sharing. Extrinsic reward has a negative impact and intrinsic reward has a positive impact. However, it cannot be assumed that compensation is influential on knowledge sharing in the electronic industry of Iran although many studies (e.g. Low \& Mohammed, 2005; Wang \& Noe, 2010; Fong et al., 2011; Asgharian et al., 2013) have focused a lot on it.

The impact of performance evaluation on knowledge sharing is not significant because p-value is .072 , which is more than .05. Previously, Wang and Noe (2010) proposed that it is better to conduct some studies on the relationship of performance evaluation and knowledge sharing but this study did not find this relation, significant Therefore, performance appraisal in the electronic industry of Iran does not have a significant impact on knowledge sharing.

One of the important factors, that has been considered as a gap in this research is participation. The results of this study have shown that participation has a significant impact on knowledge sharing because the p-value is zero and the estimated coefficient is .564. 
Asking for help from the employees in decision making at different levels especially managers and engineers, is one of the factors that can lead to the increase of knowledge sharing. It means that when the employees feel that their suggestions are important, then they will have more tendencies for knowledge sharing. Selecting participation as one of the important HRM practices has been done in order to fill the gap in previous researches. Hence, as an important and new conclusion, the impact of participation on knowledge sharing is significant and positive.

Out of the 5 components of transformational leadership's, except inspirational communication and supportive leadership other components have significant impact on knowledge sharing. Related to vision, intellectual stimulation, and personal recognition, the obtained results can be assumed to be consistent with previous researches by Low and Mohammed (2005), Asgharian et al. (2013).

As it was expected before, the impact of knowledge sharing on technical innovation is significant because p-value is zero. The obtained results are consistent with the results from previous studies by Lin (2007), Liao et al. (2008), Wang et al. (2009), and Zohoori et al. (2013).

By considering the need of the electronic industry in Iran for development and advancement, this study found out that it is better for the development of the industry to increase its technical innovation. As it was mentioned in chapter 1 and 2, most of the studies propose using knowledge sharing, hence, for enhancing the technical innovation, knowledge sharing should increase. In addition, based on the literature review, some variables such as HRM practices and transformational leadership are able to impact the technical innovation. The findings show the significant and positive role of factors such as training, participation, vision, intellectual stimulation, and personal recognition on innovation. Therefore, any programming and planning for improving these factors will lead to the increase of technical innovation in the electronic industry of Iran.

In addition, this research showed that the impact of training, staffing, participation, vision, intellectual stimulation, personal recognition, and supportive leadership on knowledge sharing is significant. Thus, given the fact that knowledge sharing has a positive impact on technical innovation, we can conclude that the electronic industry of Iran can help by planning to increase these factors in knowledge sharing and finally, innovation will be improved.

\subsection{Recommendation Future Study}

According to the obtained results, some factors have significant impacts on knowledge sharing and innovation, the electronic industry of Iran can improve these factors to increase knowledge sharing and innovation. Moreover, the results extremely support the impact of knowledge sharing on innovation, so using any method for improving knowledge donating and collecting will be recommended.

Although there are several theories (e.g. social exchange, social capital, and RBV) to support the relationship between HRM practices and knowledge sharing, there is not enough empirical research to investigate this relationship.

For future researches, it is suggested that the proposed framework of this study is tested in other industries and other countries because the role of innovation is important in any industry.

This study, according to the need of the electronic industry in Iran, was focused only on technical innovation but future researches can also examine administrative innovation.

Since the estimated coefficient is equal to .503 in the relationship between knowledge sharing and innovation, perhaps we can find another variable from the literature review along with knowledge sharing in order to help improve innovation (See Figure 2).

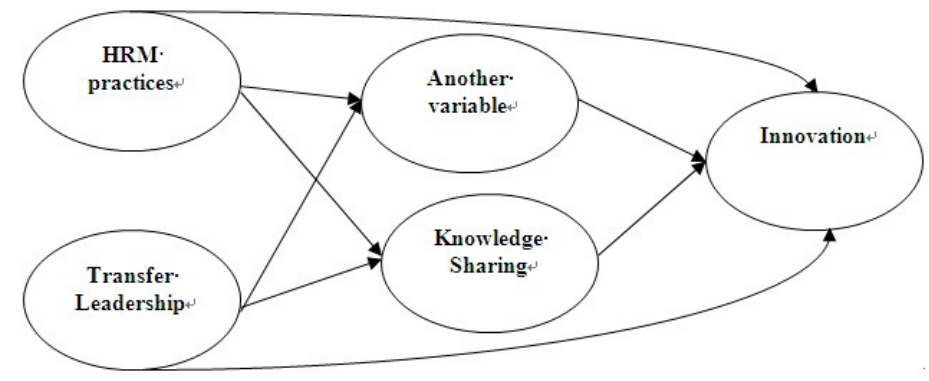

Figure 2. Proposed framework for future study 
Although this study was not concentrated on the job satisfaction as a variable which can influence knowledge sharing or innovation, it can be seen in the background of motivational factors (as it is discussed in the Wang and Noe's (2010) research). Besides, Low and Mohammed (2005) explored job satisfaction as an influential factor on knowledge sharing. However, job satisfaction is recommended for future study to complete this framework (Figure 2).

\section{References}

Ahmadi, A., Afrazeh, A., \& Bagheri, M. N. (2012). Methodological steps in analysing the development of emerging technologies using technological innovation systems: The case of fuel cell technology. In the proceedings of The 2nd International Conference of Management of Technology. IRAMOT, Tehran, Iran.

Argote, L. (1999). Organizational learning Creating, retaining and transferring knowledge. Boston, USA: Kluwer Academic Publishers.

Argote, L., McEvily, B., \& Reagans, R. (2003). Managing knowledge in organizations: An integrative framework and review of emerging themes. Manage Sci., 49(4), 571-582. http://dx.doi.org/10.1287/mnsc. 49.4.571.14424

Arzi, S., Rabanifard, N., Nassajtarshizi, S., \& Omran, N. (2013). Interdisciplinary Journal of Contemporary Research in Business, 5(6), 115-141.

Asgharian, R., Zohoori, M., Malakouti, M., \& Attarnezhad. (2013). Factors influencing knowledge sharing toward innovation: A study of electronic industry of Iran. Interdisciplinary Journal of Contemporary Researching Business (IJCRB), 5(1), 708-721.

Atuahene-Gima, K. (1996). Differential potency of factors affecting innovation performance in manufacturing and services firms in Australia. J Prod Innov Manag, 13(1), 35-52. http://dx.doi.org/10.1016/0737-6782 (95)00090-9

Bagozzi, R. P., \& Yi, Y. (1988). On the evaluation of structural equation models. Journal of the Academy of Marketing Science, 16(1), 74-94. http://dx.doi.org/10.1007/BF02723327

Baldwin, J. R., \& Gu, W. (2004). Trade liberalization: Export-market participation, productivity growth, and innovation. Oxford Review of Economic Policy, 20(3), 372-392. http://dx.doi.org/10.1093/oxrep/grh022

Barney, J. B. (1986). Strategic factor markets: Expectations, luck, and business strategy. Management Science, 42, 1231-1241. http://dx.doi.org/10.1287/mnsc.32.10.1231

Barney, J. B. (1991). Firm resources and sustained competitive advantage. Journal of Management, 17(1), 99-120. http://dx.doi.org/10.1177/014920639101700108

Barney, J. B. (1995). Gaining and sustainable competitive advantage. New York: Addison-Wesly, Ch 5.

Barney, J. B. (1995). Looking inside for competitive advantage. Academy of Management Executive, 9(4), 49-61. http://dx.doi.org/10.5465/AME.1995.9512032192

Barney, J. B. (2001). Is the resource-based 'view' a useful perspective for strategic management research? Yes. Academy of Management Review, 26(1), 41-56. http://dx.doi.org/10.2307/259393

Barney, J. B., \& Wright, P. M. (1998). On becoming a strategic partner: The role of human resources in gaining competitive advantage. Human Resource Management, 37(1), 31-46. http://dx.doi.org/10.1002/(SICI) 1099-050X(199821)37:1<31::AID-HRM4>3.0.CO;2-W

Baron, R. M., \& Kenny, D. A. (1986). The moderator-mediator variable distinction in social psychological research: Conceptual, strategic, and statistical considerations. Journal of personality and social psychology, 51(6), 1173. http://dx.doi.org/10.1037/0022-3514.51.6.1173

Beatty, R. W., \& Schneier, C. E. (1997). New HR roles to impact organizational performance: from "partners" to "players". Hum Resour Manag, 36(1), 29-37. http://dx.doi.org/10.1002/(SICI)1099-050X(199721)36:1<29:: AID-HRM7>3.0.CO;2-Y

Brockbank, W. (1999). If HR were really strategically proactive: Present and future directions in HR's contribution to competitive advantage. Hum Resour Manag, 38(4), 337-352. http://dx.doi.org/10.1002/(SICI) 1099-050X (199924)38:4<337::AID-HRM8>3.0.CO;2-5

Cabrera, E. F., \& Cabrera, A. (2005). Fostering knowledge sharing through people management practices. The International Journal of Human Resource Management, 16(5), 720-735. http://dx.doi.org/10.1080/09585 190500083020 
Cassiman, B., Golovko, E., \& Martínez-Ros, E. (2010). Innovation, exports and productivity. International Journal of Industrial Organization, 28(4), 372-376. http://dx.doi.org/10.1016/j.ijindorg.2010.03.005

Chen, C. J., \& Huang, J. W (2009), Strategic human resource practices and innovation performance - The mediating role of knowledge management capacity. Journal of Business Research, 62, 104-114. http://dx.doi.org/10.1016/j.jbusres.2007.11.016

Chiang, Y. H., \& Hung, K. P. (2010). Exploring open search strategies and perceived innovation performance from the perspective of inter-organizational knowledge flows. R\&D Management, 40, 292-299. http://dx.doi.org/10.1111/j.1467-9310.2010.00588.x

Childers, W. H. (2009). Transformational leadership and its relationship to trust and behavioural integrity. Doctoral dissertation, Sl: sn.

Cohen, W. M., \& Levinthal, D. A. (1989). Innovation and learning: two faces of R\&D. The Economic Journal, 99(397), 569-596. http://dx.doi.org/10.2307/2233763

Cohen, W. M., \& Levinthal, D. A. (1990). Absorptive capacity: A new perspective on learning and innovation. Administrative Science Quarterly, 35(1), 128-152. http://dx.doi.org/10.2307/2393553

Collins, C. J., \& Clark, K. D. (2003). Strategic human resource practices, top management team social networks, and firm performance: The role of human resource practices in creating organizational competitive advantage. Academy of Management Journal, 46(6), 740-751. http://dx.doi.org/10.2307/30040665

Currie, G., \& Kerrin, M. (2003). Human resource management and knowledge management: Enhancing knowledge sharing in a pharmaceutical company. Int J Hum Resour Manag, 14(6), 1027-1045. http://dx.doi.org/10.1080/0958519032000124641

Damanpour, F. (1991). Organizational innovation: A meta-analysis of effects of determinants and moderators. Acad Manage J., 34(3), 555-590. http://dx.doi.org/10.2307/256406

Dimitris, B., Konstantinos, K., Klas Eric, S., \& Gregory, P. (2007). Knowledge effectiveness, social context and innovation. Journal of Knowledge Management, 11, 31. http://dx.doi.org/10.1108/13673270710819780

Dyer, J., \& Nobeoka, K. (2002). Creating and managing a high performance knowledge-sharing network: The Toyota case.

Edquist, C., \& Johnson, B. (1997). Institutions and organisations in systems of innovation. In C. Edquist (Ed.), Systems of Innovation: Technologies, Institutions and Organizations. London and Washington: Pinter/Cassell Academic.

Fong, C. Y., Ooi, K. B., Tan, B. I., Lee, V. H., \& Chong, A. Y. L. (2011). HRM practices and knowledge sharing: An empirical study. International Journal of Manpower, 32(5/6), 704-723. http://dx.doi.org/10.1108/01437 721111158288

Fornell, C., \& Larcker, D. F. (1981). Evaluating structural equation models with unobservable variables and measurement error. Journal of Marketing Research, 18(1), 39-50. http://dx.doi.org/10.2307/3151312

Freeman, C., \& Soete, L. (1997). The Economics of Industrial Innovation (3rd ed.). Cambridge, The MIT Press Edition.

Galunic, D. C., \& Rodan, S. (1998). Resource recombination's in the firms: Knowledge structures and the potential for Schumpeterian innovation. Strateg Manage J., 19(12), 1193-1201. http://dx.doi.org/10.1002/ (SICI)1097-0266(1998120)19:12<1193::AID-SMJ5>3.0.CO;2-F

García-Morales, V. J., Lloréns-Montes, F. J., \& Verdú-Jover, A. J. (2007). Influence of personal mastery on organizational performance through organizational learning and innovation in large firms and SMEs. Technovation, 27(9), 547-568. http://dx.doi.org/10.1016/j.technovation.2007.02.013

Gillespie, N. A., \& Mann, L. (2004). Transformational leadership and shared values: The building blocks of trust. Journal of Managerial Psychology, 19(6), 588-607. http://dx.doi.org/10.1108/02683940410551507

Glynn, M. A. (1996). Innovative genius: A framework for relating individual and organizational intelligences to innovation. Acad Manage J., 21(4), 1081-1111. http://dx.doi.org/10.2307/259165

Grant, R. M. (1996). Toward a knowledge-based theory of the firm. Strategic Management Journal, 17, 109-122. http://dx.doi.org/10.1002/smj.4250171110

Gumusluoglu, L., \& Ilsev, A. (2009), Transformational leadership, creativity, and organizational innovation. Journal of Business Research, 62, 461-473. http://dx.doi.org/10.1016/j.jbusres.2007.07.032 
Guthrie, J. P. (2001). High-involvement work practices, turnover, and productivity: Evidence from New Zealand. Acad Manage J., 44(1), 180-190. http://dx.doi.org/10.2307/3069345

Haas, M. R., \& Hansen, M. T. (2005). When using knowledge can hurt performance: The value of organizational capabilities in a management consulting company. Strategic Management Journal, 26(1), 1-24. http://dx.doi.org/10.1002/smj.429

Hair, J. F., Anderson, R. E., Tatham, R. L., \& Black, W. C. (1995). Multivariate Data Analysis with Readings (4th ed.). Englewood Cliffs, NJ: Prentice Hall.

Hair, J. F., Black, W. C., Babin, B. J., \& Anderson, R. E. (2010). Multivariate data analysis (7th ed.). Englewood Cliffs: PrenticeHall.

Hair, J. F., Bush, R. B., \& Ortinau, D. J. (2003). Marketing Research within a Changing Information Environment. New York, NY: McGraw-Hill.

Hamidifar, F. (2010). A study of the relationship between leadership styles and employee job satisfaction at Islamic Azad University Branches in Tehran, Iran. AU-GSB e-J., 3, 45-58.

Hashi, I., \& Stojcic, N. (2013). The impact of innovation activities on firm performance using a multi stage model: Evidence from the community Innovation. Research Policy, (42), 353-366. http://dx.doi.org/10. 1016/j.respol.2012.09.011

Henderson, R., \& Cockburn, I. (1994). Measuring competence: Exploring firm effects in pharmaceutical research. Strateg Manage J., 15, 63-84. http://dx.doi.org/10.1002/smj.4250150906

Howell, J. M., \& Higgins, C. A. (1990). Champions of technological innovation. Administrative Science Quarterly, 35, 317-341. http://dx.doi.org/10.2307/2393393

Hu, M. C. (2012). Technological innovation capabilities in the thin film transistor-liquid crystal display industries of Japan, Korea, and Taiwan. Research Policy, 41(3), 541-555. http://dx.doi.org/10.1016/j.respol. 2011.10.013

Huselid, M. A. (1995). The impact of human resource management on turnover, productivity, and corporate financial performance. Academy of Management Journal, 38(3), 635-672. http://dx.doi.org/10.2307/256741

Jaw, B., \& Liu, W. (2003). Promoting organizational learning and self-renewal in Taiwanese companies: the role of HRM. Hum Resour Manag., 42(3), 223-241. http://dx.doi.org/10.1002/hrm.10082

Jiménez-Jiménez, D., \& Sanz-Valle, R. (2005). Innovation and human resource management fit: An empirical study. Int J Manpow, 26(4), 364-381. http://dx.doi.org/10.1108/01437720510609555

Jiménez-Jiménez, D., \& Sanz-Valle, R. (2011). Innovation, organizational learning, and performance. Journal of Business Research, 64(4), 408-417. http://dx.doi.org/10.1016/j.jbusres.2010.09.010

Kirner, E., Kinkel, S., \& Jaeger, A. (2009). Innovation paths and the innovation performance of low-technology firms - An empirical analysis of German industry. Research Policy, 38, 447-458. http://dx.doi.org/10.1016/j. respol.2008.10.011

Kline, R. B. (1998). Principles and Practice of Structure Equation Modelling (1st ed.). New York: The Guildford Press.

Kline, R. B. (2005). Principles and Practice of Structural Equation Modelling (2nd ed.). New York: The Guilford Press.

Kogut, B., \& Zander, U. (1992). Knowledge of the firm, combinative capabilities, and the replication of technology. Organ Sci., 3, 383-397. http://dx.doi.org/10.1287/orsc.3.3.383

Lado, A. A., \& Wilson, M. C. (1994). Human resource systems and sustained competitive advantage: A competency-based perspective. Acad Manage Rev, 19(4), 699-727. http://dx.doi.org/10.2307/258742

Laursen, K., \& Foss, N. J. (2003). New human resource management practices, complementarities, and the impact on innovation performance. Camb J Econ, 27(2), 243-263. http://dx.doi.org/10.1093/cje/27.2.243

Lee, J. H., Kim, Y. G., \& Kim, M. Y. (2006). Effects of managerial drivers and climate maturity on knowledge-management performance: Empirical validation. Information Resources Management Journal, 19(3), 48-60. http://dx.doi.org/10.4018/irmj.2006070104 
Liao, L. F. (2008). Knowledge-sharing in R\&D departments: A social power and social exchange theory perspective. The International Journal of Human Resource Management, 19(10), 1881-1895. http://dx.doi.org/10.1080/09585190802324072

Lin, H. F. (2007). Knowledge sharing and firm innovation capability: An empirical study. International Journal of Manpower, 28(3/4), 315-332. http://dx.doi.org/10.1108/01437720710755272

Liu, J., Siu, O. L., \& Shi, K. (2010). Transformational Leadership and Employee Well-Being: The Mediating Role of Trust in the Leader and Self-Efficacy. Applied Psychology, 59(3), 454-479. http://dx.doi.org/10. 1111/j.1464-0597.2009.00407.x

Low, L. S. W., \& Mohammed, A. H. (2005). The development of knowledge sharing culture in construction industry. In Proceedings Of The 4th Micra Conference. Faculty of the Built Environment, University of Malaya, Kuala Lumpur, Malaysia.

Lu, L., Leung, K., \& Koch, P. T. (2006). Managerial knowledge sharing: the role of individual, interpersonal, and organization. Review, 2, 15-41.

Lundvall, B. A.. (Ed.). (1992). National Systems of Innovation: Towards a Theory of Innovation and Interactive learning. London: Pinter.

Madsen, A. S., \& Ulhøi, J. P. (2005). Technology innovation, human resources and dysfunctional integration. Int J Manpow, 26(6), 488-501. http://dx.doi.org/10.1108/01437720510625412

Maragh, K. A. (2011). The nurse leader as change agent and role model: Thoughts of a new nurse manager. Nurse Leader, 9(3), 39-42. http://dx.doi.org/10.1016/j.mnl.2010.09.007

Martinsons, M. G. (1995). Knowledge-based systems leverage human resource management expertise. Int $J$ Manpow, 16(2), 17-34. http://dx.doi.org/10.1108/01437729510085747

Masood, T. (2010). Impact of Human Resource Management (HRM) Practices on Organizational Performance: A Mediating Role of Employee Performance. Doctoral dissertation, Mohammad Ali Jinnah University, Karachi.

Michie, J., \& Sheehan, M. (1999). HRM practices, R\&D expenditure and innovative investment: Evidence from the UK's 1990 workplace industrial relations survey (WIRS). Ind Corp Change, 8(2), 211-234. http://dx.doi.org/10.1093/icc/8.2.211

Moghadam, N. B., Hosseini, S. H., \& SahafZadeh, M., (2012). An analysis of the industry-government-university relationships in Iran's power sector: A benchmarking approach. Technology in Society, 34, 284-294. http://dx.doi.org/10.1016/j.techsoc.2012.09.001

Moghaddam, N. B., Mousavi, S. M., Nasiri, M., Moallemi, E. A., \& Yousefdehi, H. (2011). Wind energy status of Iran: Evaluating Iran's technological capability in manufacturing wind turbines. Renewable and Sustainable Energy Reviews, 15(8), 4200-4211. http://dx.doi.org/10.1016/j.rser.2011.07.029

Moorman, C., \& Miner, A. S. (1998). Organizational improvisation and organizational memory. Acad Manage Rev, 23(4), 698-723. http://dx.doi.org/10.2307/259058

Morrow, P. C., McElroy, J. C., \& Scheibe, K. P. (2012). Influencing organizational commitment through office redesign. Journal of Vocational Behavior. http://dx.doi.org/10.1016/j.jvb.2012.05.004

Mumford, M. D. (2000). Managing creative people: strategies and tactics for innovation. Hum Resour Manage Rev, 10(3), 313-351. http://dx.doi.org/10.1016/S1053-4822(99)00043-1

Mumford, M. D., Scott, G. M., Gaddis, B., \& Strange, J. M. (2002). Leading creative people: Orchestrating expertise and relationships. Leadership Quarterly, 13(6), 705-750. http://dx.doi.org/10.1016/S1048-9843 (02)00158-3

Nonaka, I., \& Konno, N. (1998). The concept of 'Ba': Building a foundation for knowledge creation. Calif Manage Rev, 40(3), 40-54. http://dx.doi.org/10.2307/41165942

Nonaka, I., \& Takeuchi, H. (1995). The knowledge-creating company. New York: Oxford University Press.

Nunnally, J. C. (1978). Psychometric Theory (2nd ed.). New York: McGraw-Hill.

OECD. (2004). Small and medium-sized enterprises in Turkey: Issues and policies. Paris: OECD.

Pfeffer, J. (1994). Competitive advantage through people. Boston, MA: Harvard Business School Press. 
Pfeffer, J. (1998). The Human Equation: Building Profits by Putting People First. Boston: Harvard Business School Press.

Pfeffer, J., \& Davis-Blake, A. (1987). Understanding organizational wage structures: A resource dependence approach. Academy of Management Journal, 30(3), 437-455. http://dx.doi.org/10.2307/256008

Piva, M., \& Vivarelli, M. (2009). The Role of Skills as a Major Driver of Corporate R\&D. International Journal of Manpower, 30, 835-852. http://dx.doi.org/10.1108/01437720911004452

Rafferty, A. E., \& Griffin, M. A. (2004). Dimensions of transformational leadership: Conceptual and empirical extensions. The Leadership Quarterly, 15, 329-354. http://dx.doi.org/10.1016/j.leaqua.2004.02.009

Renzl, B. (2008). Trust in management and knowledge sharing: The mediating effects of fear and knowledge documentation. Omega, 36(2), 206-220. http://dx.doi.org/10.1016/j.omega.2006.06.005

Robertson, P. L., \& Patel, P. R. (2007). New wine in old bottles: Technological diffusion in developed economies. Research Policy, 36(5), 708-721. http://dx.doi.org/10.1016/j.respol.2007.01.008

Runhua, T. (2011). Eliminating technical obstacles in innovation pipelines using CAIs. Computers in Industry, 62(4), 414-422. http://dx.doi.org/10.1016/j.compind.2010.12.004

Saviotti, P. P., \& Nooteboom, B. (Eds.). (2000). Technology and knowledge, from the firm to innovation systems. Cheltenham: Edward Elgar.

Scarbrough, H. (2003). Knowledge management, HRM and the innovation process. Int J Manpow, 24(5), 501-516. http://dx.doi.org/10.1108/01437720310491053

Scarbrough, H., \& Carter, C. (2000). Investigating knowledge management. London: CIPD.

Seo, D., \& Hwang, H. D. (2012). The Impact of EU's R\&D focused policy on the Innovation Edge of Mobile Industry. Procedia - Social and Behavioral Sciences, 62, 595-601. http://dx.doi.org/10.1016/j.sbspro.2012. 09.100

Shao, Z., Feng, Y., \& Liu, L. (2012). The mediating effect of organizational culture and knowledge sharing on transformational leadership and Enterprise Resource Planning systems success: An empirical study in China. Computers in Human Behavior, 28, 2400-2413. http://dx.doi.org/10.1016/j.chb.2012.07.011

Snell, S. A., Youndt, M. A., \& Wright, P. M. (1996). Establishing a framework for research in strategic human resource management: merging resource theory and organizational learning. In G. R. Ferris (Ed.), Research in Personnel and Human Resources Management (pp. 61-90). Greenwich, CT: JAI Press.

Sobel, M. E. (1982). Asymptotic confidence intervals for indirect effects in structural equation models. Sociological methodology, 13, 290-312. http://dx.doi.org/10.2307/270723

Spender, J. C. (1996). Making knowledge the basis of a dynamic theory of the firm. Strateg Manage J., 17(10), 45-62. http://dx.doi.org/10.1002/smj.4250171106

Szulanski, G. (1996). Exploiting internal stickiness: Impediments to the transfer of best practice. Strateg Manage J., 17, 27-43. http://dx.doi.org/10.1002/smj.4250171105

Teece, D. J., Pisano, G., \& Shuen, A. (1997). Dynamic capabilities and strategic management. Strategic Management Journal, 18(7), 509-533. http://dx.doi.org/10.1002/(SICI)1097-0266(199708)18:7<509::AIDSMJ882>3.0.CO;2-Z

Torraco, R. J., \& Swanson, R. A. (1995). The strategic roles of human resource development. Hum Resour Plann, 18(4), 10-21.

Totterdell, M., Heilbronn, R., Bubb, S., \& Jones, C. (2002) Evaluation of the Effectiveness of the Statutory Arrangements for the Induction of Newly Qualified Teachers. Research brief and report No.338 DfES: London.

Tsai, W. (2002). Social structure of "competition" within a multiunit organization: Coordination, competition, and intra-organizational knowledge sharing. Organ Sci., 13(2), 179-190. http://dx.doi.org/10.1287/orsc. 13.2.179.536

Tsai, W., \& Ghoshal, S. (1998). Social capital and value creation: The role of intrafirm networks. Academy of Management Journal, 41(4), 464-476. http://dx.doi.org/10.2307/257085 
Van Den Hooff, B., \& De Ridder, J. A. (2004). Knowledge sharing in context: The influence of organizational commitment, communication climate and CMC usage on knowledge sharing. Journal of Knowledge Management, 8(6), 117-130. http://dx.doi.org/10.1108/13673270410567675

von Krogh, G. (1998). Care in knowledge creation. California Management Review, 40(3), 133-153. http://dx.doi.org/10.2307/41165947

von Krogh, G., Ichijo, K., \& Nonaka, I. (2000). Enabling knowledge creation: How to unlock the mystery of tacit knowledge and release the power of innovation. New York, USA: Oxford University Press. http://dx.doi.org/10.1093/acprof:oso/9780195126167.001.0001

Waldman, D. A., \& Atwater, L. E. (1994). The nature of effective leadership and championing processes at different levels in an R\&D hierarchy. The Journal of High Technology Management Research, 5(2), 233-245. http://dx.doi.org/10.1016/1047-8310(94)90004-3

Wang, C. C. (2004). The influence of ethical and self-interest concerns on knowledge sharing intentions among managers: An empirical study. International Journal of Management, 21(3), 370-381.

Wang, D., \& Shyu, C. (2008). Will the strategic fit between business and HRM strategy influence HRM effectiveness and organisational performance? International Journal of Manpower, 29(2), 92. http://dx.doi.org/10.1108/01437720810872677

Wang, D., Xue, H., \& Xu, J. (2009). The Mechanism of Leadership Styles Affecting Team Innovation in the PRC, 978.

Wang, S., \& Noe, R. A. (2010). Knowledge sharing: A review and directions for future research. Human Resource Management Review, 20(2), 115-131. http://dx.doi.org/10.1016/j.hrmr.2009.10.001

Wang, Z., \& Wang, N. (2012). Knowledge sharing, innovation and firm performance. Expert Systems with Applications, 39, 8899-8908. http://dx.doi.org/10.1016/j.eswa.2012.02.017

Wasko, M. M., \& Faraj, S. (2005). Why should I share? Examining social capital and knowledge contribution in electronic networks of practice. MIS Quarterly, 29(1), 35-57.

Wei, C. C., Choy, C. S., Chew, G. G., \& Yen, Y. Y. (2012). Knowledge sharing patterns of undergraduate students. Library Review, 61(5), 327-344. http://dx.doi.org/10.1108/00242531211280469

Weisberg, R. W. (2006). Expertise and reason in creative thinking: Evidence from case studies and the laboratory. In J. C. Kaufman, \& J. Baer (Eds.), Creativity and Reason in Cognitive Development. Cambridge: Cambridge University Press. http://dx.doi.org/10.1017/CBO9780511606915.003

Wright, P. M., \& McMahan, G. C. (1992). Theoretical perspectives for strategic human resource management. Journal of Management, 18(2), 295-320. http://dx.doi.org/10.1177/014920639201800205

Wright, P. M., \& Snell, S. A. (1991). Toward an integrative view of strategic human resource management. Human Resource Management Review, 1, 203-225. http://dx.doi.org/10.1016/1053-4822(91)90015-5

Wright, P. M., Dunford, B. B., \& Snell, S. A. (2001). Human resources and the resource based view of the firm. Journal of Management, 27(6), 701-721. http://dx.doi.org/10.1177/014920630102700607

Wright, P. M., Gardner T. M., \& Moynihan, L. M. (2003). The impact of HR practices on the performance of business units. Human Resource Management Journal, 13(3). http://dx.doi.org/10.1111/j.1748-8583.2003. tb00096.x

Youndt, M. A., Snell, S. A., Dean, J. W., \& Lepak, D. P. (1996). Human resource management, manufacturing strategy, and firm performance. Academy of Management Journal, 39(4), 836-866. http://dx.doi.org/10. $2307 / 256714$

Youndt, M. A., Subramaniam, M., \& Snell, S. A. (2004). Intellectual capital profiles: An examination of investments and returns. Journal of Management Studies, 41(2), 335-361. http://dx.doi.org/10.1111/j.14676486.2004.00435.x

Yukl, G. (2006). Leadership in organizations. Upper Saddle River, NJ: Pearson/Prentice Hall.

Zohoori, M., Mohseni, S., Samadi, B., \& Attarnezhad, O. (2013). The relationship between knowledge sharing and innovation performance in electronic industry of Iran. Interdisciplinary Journal of Contemporary Research in Business (IJCRB), 5(1), 722-729. 


\section{Appendix A}

Table A1. Measure of the constructs and descriptive analysis

Mean SD Skewness Kurtosis

\section{HRM practice}

\section{Training}

1. Formal training activities are available in my company

7. The organization has a system for calculating the cost and benefit of training.

\section{Staffing}

1. Recruitment \& selection system followed in our organization is well defined

2. In our organization, line managers and HRM managers participate in recruitment $\&$ selection

3. Valid and standardized tests are used in the selection process of employees.

4. Our organization uses comprehensive selection process before making a decision.

5. The organization uses assessment centers for selection

6. We have clear criteria for employee selection.

7. We use attitude and desire to work in a team and as an individual as a criterion in selection

8. Our organization uses tests and interviews for selection.

\section{Performance Appraisal}

1. Performance is measured on the basis of objectives and quantifiable results

2. Appraisal system in our organization is growth and development oriented.

3. Employees are provided performance based feedback and counseling.

4. Appraisal system is unbiased and transparent

5. Appraisal information is used for bonuses, promotions and selecting training

6.Everybody working in the organization have clear understanding of the objectives of performance appraisal

7. Appraisal system is constantly reviewed and updated with latest techniques and technology.

8. Appraisal system has a strong influence on individual and team behavior

9. Our organization conducts performance appraisal and provides feedback on a regular basis.

10. In our company, performance appraisal is used for improving performance rather than for punishing.

\section{Compensation}

1. Compensation offered by our organization matches the expectancy of employees.

2. In our organization, salary and other benefits are comparable to the market.

$\begin{array}{llll}3.0053 & 1.50154 & .000 & -1.454 \\ 2.8254 & 1.40714 & .112 & -1.295 \\ 2.8730 & 1.36643 & .030 & -1.236 \\ 2.9683 & 1.44906 & -.071 & -1.361 \\ 2.8889 & 1.36975 & .009 & -1.276 \\ 2.9089 & 1.4001 & .122 & -1.091 \\ & & & \\ 3.0012 & 1.38899 & .-.346 & -1.059\end{array}$

$\begin{array}{llll}2.7831 & .197 \quad-.159 & -1.150\end{array}$

$\begin{array}{llll}2.9365 & .031 & -.264 & -1.244\end{array}$

$\begin{array}{llll}2.7831 & .242 & -.049 & -1.149\end{array}$

$\begin{array}{llll}2.9815 & -.026 & -.278 & -1.269\end{array}$

$\begin{array}{llll}2.7698 & .249 & -.104 & -1.154\end{array}$

$\begin{array}{llll}2.7884 & .236 & -.109 & -1.119\end{array}$

$\begin{array}{llll}2.8254 & 1.40714 & .112 & -1.365\end{array}$

$\begin{array}{llll}2.8730 & 1.36643 & .030 & -1.279\end{array}$

$\begin{array}{llll}3.2513 & 1.41527 & -.294 & -1.274\end{array}$

$\begin{array}{llll}3.1429 & 1.41636 & -.153 & -1.339\end{array}$

$\begin{array}{llll}3.2143 & 1.40824 & -.253 & -1.260\end{array}$

$\begin{array}{llll}3.1693 & 1.38882 & -.156 & -1.295\end{array}$

$\begin{array}{llll}3.0794 & 1.36421 & -.100 & -1.213\end{array}$

$\begin{array}{llll}3.1429 & 1.42569 & -.198 & -1.342\end{array}$

$\begin{array}{llll}3.3280 & 1.45062 & -.349 & -1.321\end{array}$

$2.7698 \quad .249 \quad-.154 \quad-1.154$

$\begin{array}{llll}2.9365 & .031 \quad-.244 \quad-1.254\end{array}$

$\begin{array}{llll}3.1280 & 1.45062 & -.449 & -1.344\end{array}$

3. In our organization compensation is decided on the basis of

$\begin{array}{llll}2.9683 & 1.48522 & -.058 & -1.408 \\ 3.0529 & 1.48462 & -.125 & -1.387 \\ 3.0106 & 1.38575 & -.163 & -1.262\end{array}$




competence of the employee
4. The compensation for all employees is directly linked to their
performance.

5. In our organization profit sharing is used as a mechanism to reward higher performance.

6. Our organization offers both financial and non-financial rewards without discrimination.

7. The compensation plan is revised accordingly with the economic situation.

8. In general, I understand why I get what I get.

Mean SD $\quad$ Skewness Kurtosis

\section{Participation}

1. Employees at each level in the organization take part in decision-making process up to an extent

2. Employees are asked by superiors to participate in related decisions.

3. Employees are provided opportunity to suggest improvements in the way things are done here.

4. Employees are trusted to make decisions for themselves and the organization

5. Our organization gives rewards for making appropriate suggestions.

6. We have a culture that promotes employee involvement in our organization.

7. We meet voluntarily to identify operational problems relevant to the organization.

8. Our organization consults employees in strategic decision-making.

9. Employees' decision freedom improves their satisfaction in our organization.

10. Employees having liberty to organize their job tasks as per their convenience produce more output.

\section{Knowledge Donating}

1. I share my knowledge with my colleagues when I have learnt something new.

2. My colleagues share with me when they have learnt new things

3. Knowledge sharing amongst colleagues is considered normal in my organization.

2.86

$\begin{array}{llll}2.8413 & 1.47164 & .050 & -1.447\end{array}$

$3.0694 \quad 1.26421 \quad-.104 \quad-1.613$

$\begin{array}{llll}3.2429 & 1.32569 & -.143 & -1.44\end{array}$

$\begin{array}{llll}2.7831 & .242 & -.149 & -1.149\end{array}$

$\begin{array}{llll}3.2121 & 1.41291 & -.280 & -1.246\end{array}$

$\begin{array}{llll}3.2121 & 1.36922 & -.232 & -1.167\end{array}$

$\begin{array}{llll}3.0661 & 1.37300 & -.029 & -1.241\end{array}$

$\begin{array}{llll}3.0882 & 1.34327 & -.148 & -1.163\end{array}$

$\begin{array}{llll}3.2452 & 1.33708 & -.233 & -1.121\end{array}$

$\begin{array}{llll}3.0992 & 1.40876 & -.219 & -1.306\end{array}$

$\begin{array}{llll}3.0529 & 1.48462 & -.125 & -1.387\end{array}$

$\begin{array}{llll}3.0106 & 1.38575 & -.163 & -1.262\end{array}$

$\begin{array}{llll}2.8413 & 1.47164 & .050 & -1.447\end{array}$

$\begin{array}{llll}3.0694 & 1.26421 & -.104 & -1.613\end{array}$

$\begin{array}{llll}2.9697 & 1.47227 & -.052 & -1.386\end{array}$

$2.9697 \quad 1.47227 \quad-.052 \quad-1.386$

$2.9807 \quad 1.37947 \quad-.156 \quad-1.272$

\section{Knowledge Collecting}

1. I am confident of my ability to access knowledge that the others in my learning environment would consider valuable

$2.8457 \quad 1.40968$

$-1.301$

2. I have the expertise required to acquire valuable knowledge from my learning environment

$\begin{array}{lll}2.8209 & 1.47292 \quad .083\end{array}$

$-1.439$

3. Most of my colleagues can provide me with valuable knowledge.

\section{Transformational Leadership}

\section{Vision}

1. The superior manager has a clear understanding of where we are going

$2.8874 \quad 1.38055 \quad .035$

$-1.301$

2. The superior manager has a clear sense of where he/she wants our unit to be in 5 years

$2.9791 \quad 1.37262-.066$

$-1.273$

3. The superior manager can clearly articulate our organization's strategic vision and objectives

$\begin{array}{llll}2.9031 & 1.31358 \quad .012 & -1.150\end{array}$

4. I feel my company is moving in the right direction toward achieving its goals

$2.9058 \quad 1.33851 \quad-.018$

$-1.204$

5. All employees can contribute in achieving company's objectives

$2.9319 \quad 1.33618 \quad-.048$

$-1.194$ 


\begin{tabular}{lllll}
\hline & Mean & SD & Skewness & Kurtosis \\
\hline $\begin{array}{l}\text { 6. Superior manager expresses with a few simple words what we } \\
\text { could and should do }\end{array}$ & 2.8457 & 1.40968 & .056 & -1.301 \\
$\begin{array}{l}\text { 7. Superior manager provides appealing images about what we can } \\
\text { achieve. }\end{array}$ & 2.8209 & 1.47292 & .083 & -1.439
\end{tabular}

\section{Inspirational communication}

1. The superior manager says things that make employees proud to be a part of this organization

2. The superior manager says positive things about the work unit

3. The superior manager encourages people to see changing environments as situations full of opportunities

4. The superior manager helps others find meaning in their work

5. The superior manager makes others feel good to be around him/her

6. I am proud to be associated with my company

\section{Intellectual stimulation}

1. The superior manager challenges me to think about old problems in new ways

$\begin{array}{llll}2.9091 & 1.36451 & .021 & -1.215 \\ 2.8926 & 1.36735 & .026 & -1.235 \\ 2.8127 & 1.35970 & .111 & -1.207 \\ 2.8623 & 1.37571 & .096 & -1.206 \\ 2.9201 & 1.30096 & .013 & -1.124 \\ 2.8237 & 1.34073 & .083 & -1.207\end{array}$

2. The superior manager has ideas that have forced me to rethink some things that I have never questioned before

3.The superior manager has challenged me to rethink some of my basic assumptions about my work

4. I am provided with new ways of looking at puzzling things.

5. We are continuously motivated to do problem solving in creative, clever ways

6. I think every employee has potential to solve company's problems

\section{Supportive leadership}

1. The superior manager considers my personal feelings before acting

2. The superior manager behaves in a manner which is thoughtful of my personal needs

3. The superior manager sees that the interests of employees are given due consideration

4. The superior manager facilitates consensus building in work group sessions

5. The superior manager has empathy and concern in dealing with subordinates

6. Company insists on minimum disruption to the work flow

7. Company gives personal attention to others who seem rejected

\section{Personal recognition}

1. The superior manager commends me when I do a better than average job

2. The superior manager acknowledges improvement in my quality of work

3. The superior manager personally compliments me when I do outstanding work

4. The superior manager listens to me when I have problem

5. My company appreciates any useful or innovative idea by giving award

$\begin{array}{llll}2.8168 & 1.45011 & .105 & -1.376\end{array}$

$\begin{array}{llll}2.9398 & 1.46849 & -.025 & -1.383\end{array}$

$\begin{array}{llll}2.9241 & 1.43704 & -.005 & -1.333\end{array}$

$\begin{array}{llll}3.0524 & 1.41695 & -.243 & -1.291\end{array}$

$\begin{array}{llll}2.8141 & 1.46687 & .109 & -1.405\end{array}$

$\begin{array}{llll}2.8351 & 1.47473 & .084 & -1.419\end{array}$

$\begin{array}{llll}3.0000 & 1.47241 & -.074 & -1.391\end{array}$

$\begin{array}{llll}3.1675 & 1.46282 & -.207 & -1.332\end{array}$

$\begin{array}{llll}2.9738 & 1.35327 & -.093 & -1.200\end{array}$

$\begin{array}{llll}2.9188 & 1.37133 & -.049 & -1.248\end{array}$

$\begin{array}{llll}2.9450 & 1.43434 & -.069 & -1.392\end{array}$

$\begin{array}{llll}2.9476 & 1.37369 & -.040 & -1.278\end{array}$

$\begin{array}{llll}3.0100 & 1.37241 & -.084 & -1.391\end{array}$

6. My company acknowledges improvement in my quality of work

7. I get recognition from my company when I do useful things.

Technical Innovation

1. Developing new technologies is important for my company

$2.9581 \quad 1.45927 \quad-.054 \quad-1.365$

$\begin{array}{llll}3.1257 & 1.45444 & -.184 & -1.313\end{array}$

$\begin{array}{llll}2.9948 & 1.32806 & -.139 & -1.175\end{array}$

$\begin{array}{llll}2.8822 & 1.41579 & .026 & -1.329\end{array}$

$\begin{array}{lllll}2.9162 & 1.42836 & -.020 & -1.389\end{array}$

$\begin{array}{lllll}2.9398 & 1.41756 & -.049 & -1.380\end{array}$

$\begin{array}{llll}2.9162 & 1.40427 & -.010 & -1.330\end{array}$

2. My company incorporates technologies into new products

$\begin{array}{llll}2.8115 & 1.32850 & .107 & -1.163\end{array}$

$\begin{array}{llll}2.9398 & 1.29162 & -.027 & -1.087\end{array}$ 


\begin{tabular}{lllll}
\hline & Mean & SD & Skewness & Kurtosis \\
\hline $\begin{array}{l}\text { 3. My company facilitates new processes to improve quality and } \\
\text { cost }\end{array}$ & 2.9398 & 1.30577 & -.023 & -1.112 \\
$\begin{array}{l}\text { 4. My company changes when it is necessary } \\
\text { 5. My company adapts new technology from external sources to }\end{array}$ & 2.9424 & 1.31290 & -.026 & -1.125 \\
grow & 2.9031 & 1.30958 & .004 & -1.122 \\
6. My company is able to create new technologies & 2.9450 & 1.43434 & -.069 & -1.392 \\
7. My company chooses proper technologies to adapt and develop & 3.1675 & 1.46282 & -.207 & -1.332 \\
\hline
\end{tabular}

Table A2. Rotated component matrix (HRM practice)

\begin{tabular}{|c|c|c|c|c|c|}
\hline & Training & Staffing & Appraisal & Compensation & Participation \\
\hline T3 & .903 & & & & \\
\hline T5 & .887 & & & & \\
\hline $\mathrm{T} 2$ & .852 & & & & \\
\hline $\mathrm{T} 4$ & .721 & & & & \\
\hline $\mathrm{T} 1$ & .641 & & & & \\
\hline ST3 & & .946 & & & \\
\hline ST6 & & .935 & & & \\
\hline ST2 & & .644 & & & \\
\hline ST5 & & .517 & & & \\
\hline ST7 & & .501 & & & \\
\hline APP4 & & & .944 & & \\
\hline APP5 & & & .883 & & \\
\hline APP3 & & & .711 & & \\
\hline APP1 & & & .651 & & \\
\hline COMP4 & & & & .899 & \\
\hline COMP3 & & & & .763 & \\
\hline COMP1 & & & & .759 & \\
\hline COMP2 & & & & .667 & \\
\hline PAR2 & & & & & .954 \\
\hline PAR6 & & & & & .901 \\
\hline PAR3 & & & & & .898 \\
\hline PAR1 & & & & & .755 \\
\hline PAR4 & & & & & .727 \\
\hline \multicolumn{6}{|c|}{$\mathrm{KMO}=.846$} \\
\hline \multicolumn{6}{|c|}{ Chi-Square $=4.810 \mathrm{E} 3$} \\
\hline \multicolumn{6}{|l|}{$\mathrm{Df}=171$} \\
\hline Sig. $=0$ & & & & & \\
\hline
\end{tabular}

Table A3. Rotated component matrix (Transformational leadership)

\begin{tabular}{lcllll}
\hline & Vision & $\begin{array}{l}\text { Inspirational } \\
\text { communication }\end{array}$ & $\begin{array}{l}\text { Intellectual } \\
\text { stimulation }\end{array}$ & $\begin{array}{l}\text { Personal } \\
\text { Recognition }\end{array}$ & $\begin{array}{l}\text { Supportive } \\
\text { leadership }\end{array}$ \\
\hline VISION4 & .985 & & & \\
VISION5 & .983 & & & \\
VISION3 & .975 & & & \\
VISION2 & .858 & & & \\
VISION7 & .777 & & & \\
INSP.COM2 & & .967 & & \\
\hline
\end{tabular}




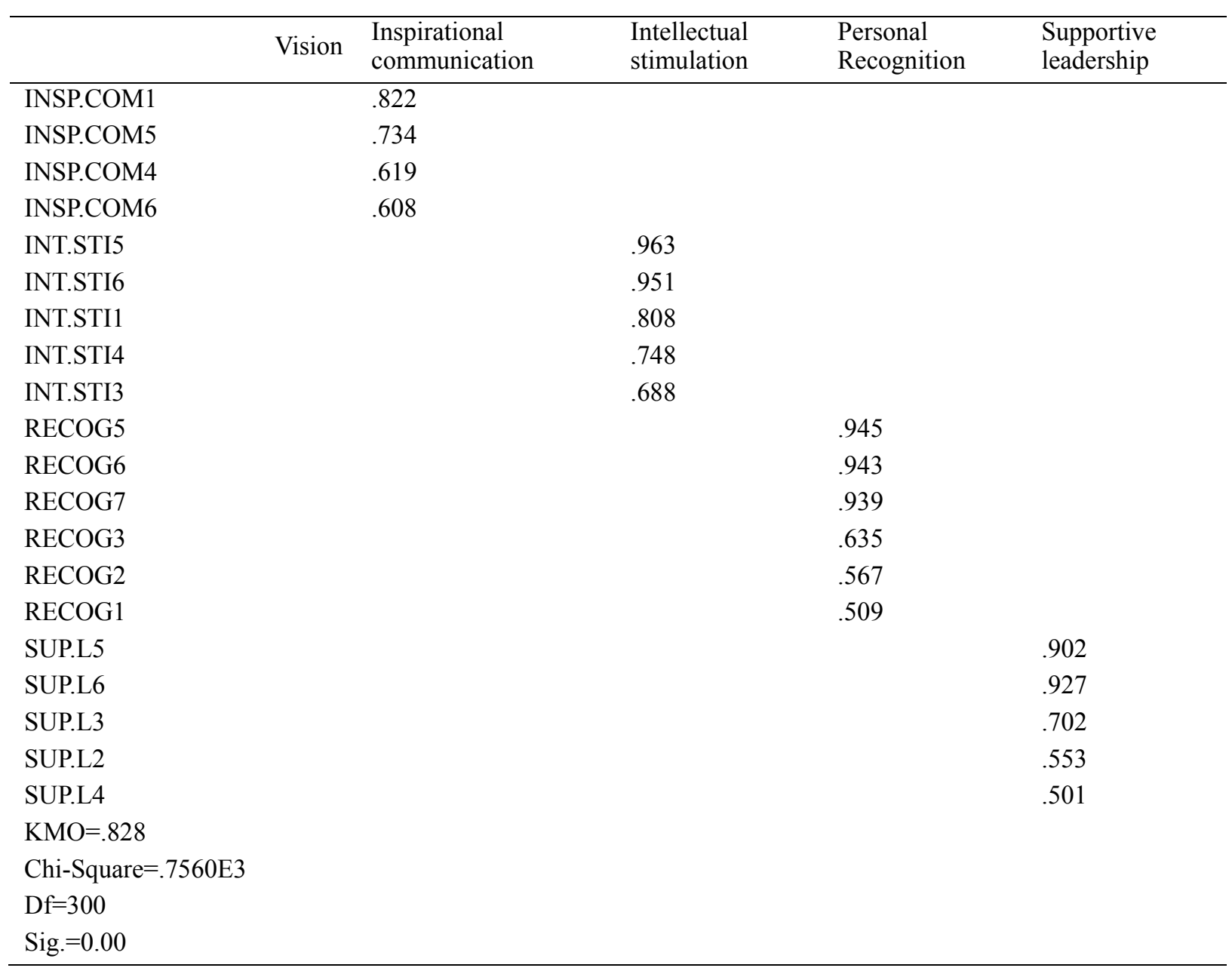

Table A4.

\begin{tabular}{|c|c|c|c|c|c|}
\hline Construct & Items & Standardized Loading & Cronbach's Alpha & $\mathrm{CR}$ & AVE \\
\hline \multicolumn{6}{|l|}{ HRM Practices } \\
\hline \multirow{5}{*}{ Training } & $\mathrm{T} 1$ & .641 & \multirow{5}{*}{.789} & \multirow{5}{*}{.886} & \multirow{5}{*}{.611} \\
\hline & $\mathrm{T} 2$ & .802 & & & \\
\hline & $\mathrm{T} 3$ & .893 & & & \\
\hline & $\mathrm{T} 4$ & .698 & & & \\
\hline & T5 & .847 & & & \\
\hline \multirow{4}{*}{ Staffing } & $\mathrm{ST} 2$ & .644 & \multirow{4}{*}{.803} & \multirow{4}{*}{.876} & \multirow{4}{*}{.656} \\
\hline & ST3 & 1.00 & & & \\
\hline & ST5 & .507 & & & \\
\hline & ST6 & .975 & & & \\
\hline \multirow{4}{*}{ Appraisal } & APP1 & .616 & \multirow{4}{*}{.705} & \multirow{5}{*}{.850} & \multirow{5}{*}{.595} \\
\hline & APP3 & .621 & & & \\
\hline & APP4 & .914 & & & \\
\hline & APP5 & .882 & & & \\
\hline \multirow{3}{*}{ Compensation } & COMP1 & .763 & \multirow{3}{*}{.767} & & \\
\hline & COMP3 & .759 & & \multirow[t]{2}{*}{.847} & \multirow[t]{2}{*}{.650} \\
\hline & COMP4 & .889 & & & \\
\hline \multirow{2}{*}{ Participation } & PAR1 & .760 & \multirow{2}{*}{.824} & \multirow{2}{*}{.933} & \multirow{2}{*}{.737} \\
\hline & PAR2 & .964 & & & \\
\hline
\end{tabular}




\begin{tabular}{|c|c|c|c|c|c|}
\hline Construct & Items & Standardized Loading & Cronbach's Alpha & $\mathrm{CR}$ & AVE \\
\hline & PAR3 & .898 & & & \\
\hline & PAR4 & .737 & & & \\
\hline & PAR6 & .910 & & & \\
\hline \multicolumn{6}{|l|}{ Transformational Leadership } \\
\hline \multirow{4}{*}{ Vision } & VISION2 & .868 & \multirow{5}{*}{.733} & \multirow{4}{*}{.979} & \multirow{5}{*}{.920} \\
\hline & VISION3 & .975 & & & \\
\hline & VISION4 & .995 & & & \\
\hline & VISION5 & .993 & & & \\
\hline \multirow{4}{*}{ Inspirational Communication } & INSP.COM1 & .81 & & \multirow{4}{*}{.867} & \\
\hline & INSP.COM2 & .977 & \multirow{3}{*}{.756} & & \multirow{3}{*}{.627} \\
\hline & INSP.COM4 & .627 & & & \\
\hline & INSP.COM5 & .71 & & & \\
\hline \multirow{5}{*}{ Intellectual Stimulation } & INT.STI1 & .818 & \multirow{5}{*}{.829} & \multirow{5}{*}{.929} & \multirow{5}{*}{.728} \\
\hline & INT.STI3 & .698 & & & \\
\hline & INT.STI4 & .758 & & & \\
\hline & INT.STI5 & .983 & & & \\
\hline & INT.STI6 & .971 & & & \\
\hline \multirow{5}{*}{ Personal Recognition } & RECOG2 & .577 & \multirow{5}{*}{.779} & \multirow{5}{*}{.936} & \multirow{5}{*}{.794} \\
\hline & RECOG3 & .695 & & & \\
\hline & RECOG5 & .995 & & & \\
\hline & RECOG6 & .993 & & & \\
\hline & RECOG7 & .989 & & & \\
\hline \multirow{4}{*}{ Supportive Leadership } & SUP.L2 & .582 & \multirow{4}{*}{.800} & \multirow{4}{*}{.893} & \multirow{4}{*}{.682} \\
\hline & SUP.L3 & .700 & & & \\
\hline & SUP.L5 & 1.00 & & & \\
\hline & SUP.L6 & .957 & & & \\
\hline \multirow{5}{*}{ Knowledge Sharing } & KS2 & .665 & \multirow{5}{*}{.831} & \multirow{5}{*}{.922} & \multirow{5}{*}{.709} \\
\hline & KS3 & .740 & & & \\
\hline & KS4 & .752 & & & \\
\hline & KS5 & .999 & & & \\
\hline & KS6 & .995 & & & \\
\hline \multirow{4}{*}{ Technical Innovation } & tech.inn 1 & .987 & \multirow{4}{*}{.729} & \multirow{4}{*}{.921} & \\
\hline & tech.inn3 & .992 & & & 740 \\
\hline & tech.inn4 & .689 & & & .149 \\
\hline & tech.inn5 & .51 & & & \\
\hline
\end{tabular}

\section{Copyrights}

Copyright for this article is retained by the author(s), with first publication rights granted to the journal.

This is an open-access article distributed under the terms and conditions of the Creative Commons Attribution license (http://creativecommons.org/licenses/by/3.0/). 